\title{
Project methods and station geomorphology related to a multi-taxon survey (2009-2014) of the Kimberley
}

\author{
Clay Bryce ${ }^{{ }^{*}}$, Monika Bryce ${ }^{1}$ and Ben Radford ${ }^{2,3}$ \\ 1 Department of Aquatic Zoology, Western Australian Museum, Locked Bag 49, Welshpool DC, \\ Western Australia 6986, Australia \\ ${ }^{2}$ School of Earth and Environment and the UWA Oceans Institute, The University of Western \\ Australia, 35 Stirling Highway, Crawley, Western Australia 6009, Australia \\ ${ }^{3}$ Australian Institute of Marine Science, UWA Oceans Institute (M096), 35 Stirling Highway, Crawley, \\ Perth, Western Australia 6009, Australia \\ * Email: clay.bryce@museum.wa.gov.au
}

\begin{abstract}
The marine environments off the Kimberley coast are being subjected to ever increasing human-induced pressures, with little known of the region's marine biodiversity, and therefore, which conservation approaches are appropriate. Consequently, the Western Australian Museum with partner agencies undertook to survey the region over a six year period (2009-2014). Thirty eight locations involving 179 survey stations were visited within the defined Project Area, which ranged from the Kimberley coast to the continental shelf edge. Geomorphic data from these stations, along with additional data from a 2006 survey, were incorporated into the analyses, providing a total of 224 survey stations. Analyses revealed a three-way differentiation of the surveyed stations demonstrating continental shelf zonation, an intertidal and subtidal distinction and a turbidity gradation.
\end{abstract}

KEYWORDS: ecological assessment, natural history collections, species inventory, Kimberley Project Area, north-west Australia, Indian Ocean, biodiversity, Woodside Collection Project

\section{INTRODUCTION}

The Kimberley marine regions off the north-west of Western Australia have always been considered remote (Halpern et al. 2008), but this status is being challenged by increasing incursions and expectations from tourism, fishing and various resource industries. The status of the marine environments and their associated flora and fauna, in the face of these increasing anthropogenic uses, is still relatively unknown (Wood and Mills 2008). The need to rectify this knowledge deficiency is now a priority and considerable effort has been, and is being made, by several agencies to remedy the situation (Wilson 2014). The Woodside Collection Project (Kimberley) 2008-2015 (the Project) was one such initiative. The Project was a multiagency initiative involving the Museum and Art Gallery of the Northern Territory, Queensland Museum, Australian Museum, Museum Victoria, the Western Australian Herbarium (WAH) and Curtin University, with Western Australian Museum (WAM) as lead agency.
The Project consisted of two components, with the first (2008-2011) being a historical assessment of the marine biological records from Australian museums and WAH within a defined area (the Project Area; Figure 1) as detailed by Sampey et al. (2014), but re-stated here for convenience. The Project Area is defined by the coordinates $19.00^{\circ} \mathrm{S}$ $121.57^{\circ} \mathrm{E} ; 19.00^{\circ} \mathrm{S} 118.25^{\circ} \mathrm{E} ; 12.00^{\circ} \mathrm{S} 129.00^{\circ} \mathrm{E} ; 12.00^{\circ} \mathrm{S}$ $121.00^{\circ} \mathrm{E}$, with the coastline forming a natural inshore boundary. This irregular polygon stretches north along the coast from Cape Jaubert, south of Broome, to the Western Australia/Northern Territory border, and extends westward beyond the $1000 \mathrm{~m}$ bathymetric contour to include the continental shelf edge atolls (Hibernia Reef to Imperieuse Reef, northernmost to southernmost respectively) (Figure 1). Wilson (2014) has reviewed the habitats, geology and historical exploration of the Project Area. The historical data concerned nine targeted marine taxa (marine plants, sponges, marine worms, hard corals, soft corals, molluscs, crustaceans, echinoderms and fishes) and have been published (Jones et al. 2017). 


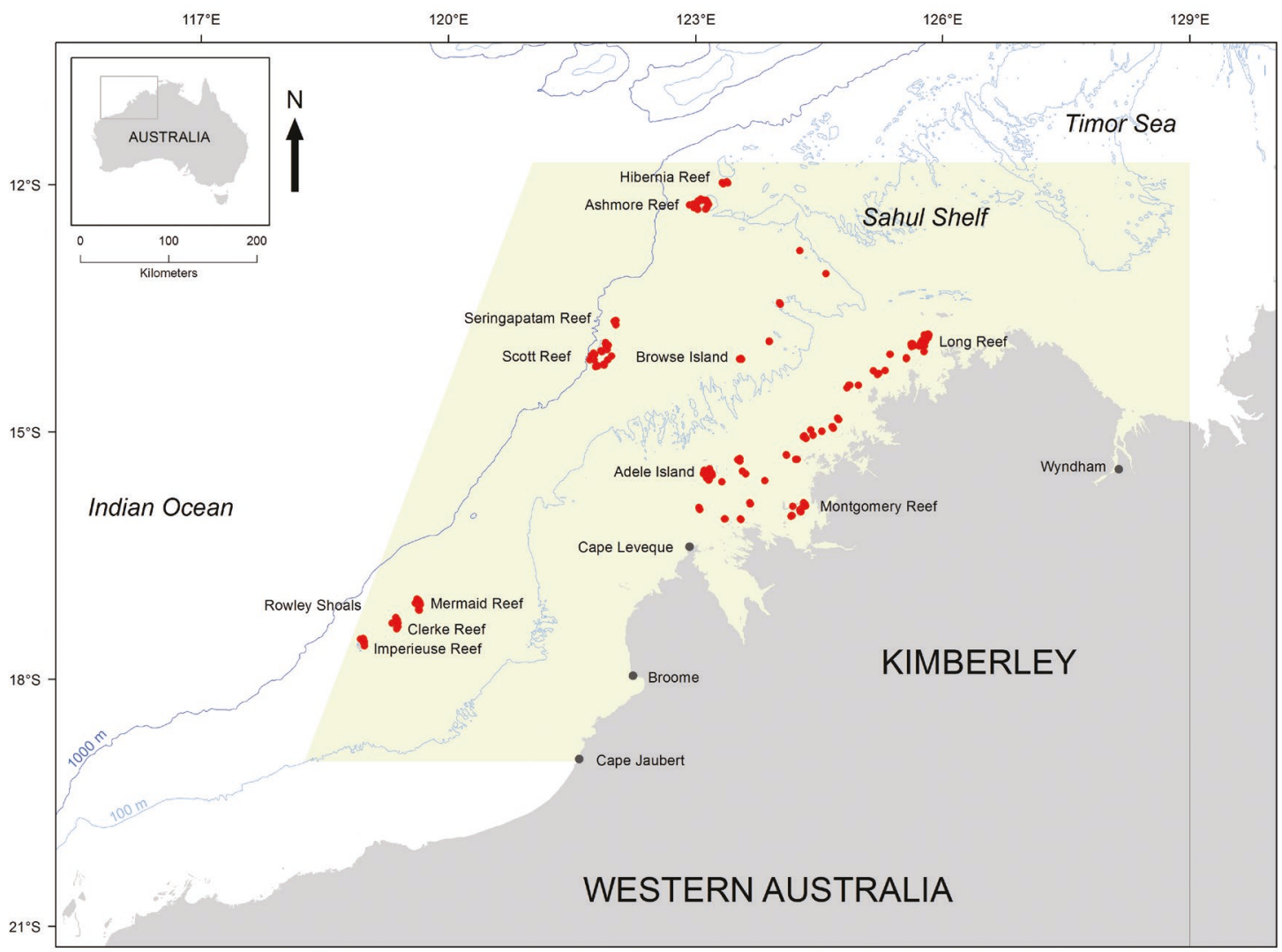

FIGURE $1 \quad$ Map depicting surveyed Project stations (2009-2014) and the survey stations undertaken in 2006 (Mermaid, Scott and Seringapatam Reefs). Station details can be found in Table 1. Project Area is delineated by the light green $\left(\sim 476,000 \mathrm{~km}^{2}\right)$.

The second component (2009-2014) of the Kimberley Project comprised a series of six surveys within the Project Area that also defined the data capture area for the historical component. This paper is the first in a series concerning these surveys, with other papers covering water quality, transect habitat data and biodiversity data from the same nine marine taxa targeted during the historical component. The scope of this initial paper is to provide an overview of the Project's general survey methodology and to present station geomorphic data and does not present biological data. As such, this paper will provide comprehensive meta-data underpinning the other papers in this series, which are currently in preparation. Method nuances, composition of collected specimen vouchers, biodiversity inventory records and transect abundance data will be detailed and discussed within each of the taxa papers constituting this series.

\section{PROJECT AIMS}

The aims of the project were threefold: to record the shallow water $(<30 \mathrm{~m})$ marine flora and fauna (restricted to fishes and targeted invertebrates - see Methods) along with associated transect habitat and geomorphic data from surveyed stations throughout the Project Area; to collect appropriate voucher specimens for lodging in Australian natural science collections; and to provide information on survey station geomorphology, biodiversity and associated biogeography.

The aim of the present paper is to provide an overview of the Project's general survey methodology and to present station geomorphic data.

\section{PROJECT METHODS}

\section{PROJECT OVERVIEW}

Marine fieldwork in the Kimberley is logistically difficult and expensive, and has significant occupational health and safety issues associated with it. Strong currents, macro-tides, dangerous marine life and the remote location require careful planning. Balancing safe work activities with subtidal and intertidal survey locations against project logistical constraints, such as available time and funding required the exclusion of mangroves and soft sediment habitats (e.g. extensive sandy spines at Montgomery and Long Reefs) from the survey program. Further rationalisations concerning Project occupational health and safety 
were also undertaken by limiting survey work away from nearshore coastal islands and river mouths where crocodile densities are highest and water turbidity a complicating factor.

The six shallow water $(<30 \mathrm{~m})$ surveys were undertaken during the months of September to October 2009-2014, one trip annually. The Project surveys ranged from Fraser Island, just north of Cape Leveque, to Long Reef in the far north Kimberley (a straight line distance of $\sim 400 \mathrm{~km}$ ); westward to the atolls and reefs at the edge of the continental shelf $(\sim 300 \mathrm{~km}$ from shore), including the midshelf shoals and Browse Island from Hibernia Reef in the north to Imperieuse Reef (Rowley Shoals) in the south $(\sim 680 \mathrm{~km})$.

The Project Area was divided into continentalshelf zones, using the following bathymetric ranges: inshore (coastal shoreline to $50 \mathrm{~m}$ ), midshelf (51-150 $\mathrm{m})$ and offshore (>150 m). Within these broad zones, locations (defined below) were chosen from the available reefs, to maximise spatial spread of the stations (defined below).

For the purpose of these surveys a 'location' was defined as a recognisable geographical point observable on standard navigation charts. The locations would fall within one of the three bathymetric zones (inshore, midshelf or offshore) contained within the Project Area. These locations may or may not have a name as confirmed by the Western Australian Geographic Names Committee. At each location one or more survey 'stations' were undertaken, defined as a geographical point adjacent to or part of a location and identified by latitude and longitude (Table 1).

The completed survey stations (Figure 1 and Table 1) spanned approximately four degrees of longitude and six degrees of latitude, within the greater Project Area $\left(\sim 476,000 \mathrm{~km}^{2}\right)$, providing significant latitudinal and longitudinal biological gradient possibilities. This coverage included many of the outer inshore island and reef groups, several of the midshelf shoals and all of the shelf-edge atolls, except for South and North Scott Reefs and Seringapatam Reef, which were surveyed by WAM in 2006, along with Mermaid Reef (Rowley Shoals) (Bryce 2009). This latter reef was re-surveyed as part of this project in 2014 (Table 2).

\section{STATION DATA OVERVIEW}

Numbering of the stations followed a sequential format from project start to finish (1-181) with differentiation made for each survey year (K9, K10, K11 etc.), i.e. station 1 would be $1 / \mathrm{K} 09$, while station 181 would read 181/K14. Stations from the 2006 Scott Reef survey were annotated as s1-s45 to differentiate them.

At all stations, except for the nine non-transect stations (Table 1 and see below), encountered targeted taxa were recorded, vouchers collected and species abundances determined. Station effort was standardised by limiting survey time to one hour. Once transect sampling had been completed any remaining time was spent off-transect recording and vouchering targeted taxa. The non-transect stations were the result of either logistical constraints (16/ K09, 121/K12 and 181/K13) or depth of water (107/ K12-109/K12 and 146/K13-148/K13). These latter stations were from the midshelf region where shallowest dive depths were approximately $20 \mathrm{~m}$ resulting in limited bottom times and complicated by an open ocean aspect rendering transect survey work risky and difficult (see Table 1). Data recorded for the non-transect stations were similar to the transect stations, except for the absence of habitat and species abundance counts.

\section{TRANSECT STATIONS}

Stations were classified as either intertidal or subtidal. At 'intertidal' stations, sponges, hard corals, soft corals, molluscs, crustaceans, echinoderms and marine worms were recorded quantitatively along $50 \mathrm{~m}$ transect tapes. Fish were collected and recorded qualitatively from tide pools, and marine plants were collected throughout the stations, but covering as many habitat types as possible. Some intertidal stations were dived or snorkelled when the sites were covered by water.

'Subtidal' dive stations were surveyed similarly to the intertidal stations. The seven invertebrate taxa were recorded along $50 \mathrm{~m}$ transects laid at approximately $12 \mathrm{~m}$ depth. Fish were recorded on depth-decreasing, timed swims of 60 minutes, equating to a swim distance between $250-300 \mathrm{~m}$. Marine plants were recorded by using a stationwide sampling approach across representative habits. It should be noted that the station transect depth and maximum depth (see Table 1) were absolute, relative to the prevailing tide height. This was necessary due to the macrotidal environment and logistics.

\section{TRANSECT BENTHIC COVER}

Where possible, subtidal and intertidal transects (except for fish and marine plants) were recorded on video or point intercept data were collected to quantify habitat cover proportions (Richards et al. 2018). Transect rugosity was also determined using a $10 \mathrm{~m}$ chain and tape method (Risk 1972) at three replicates per transect, for stations surveyed in years 2011-2014.

\section{WATER QUALITY}

Water quality measurements were recorded at most stations during 2011-2014 and these will be reported on separately. 


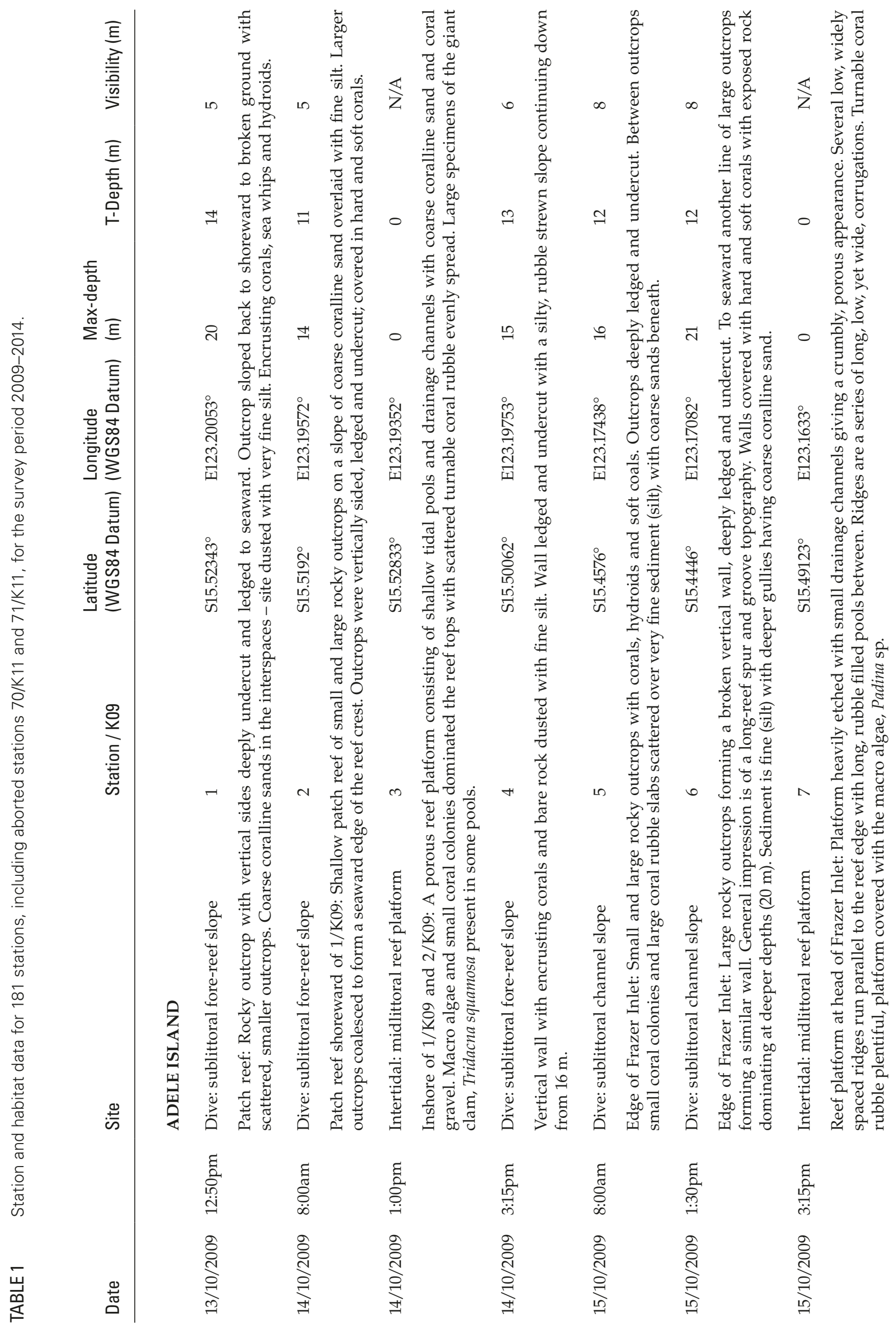




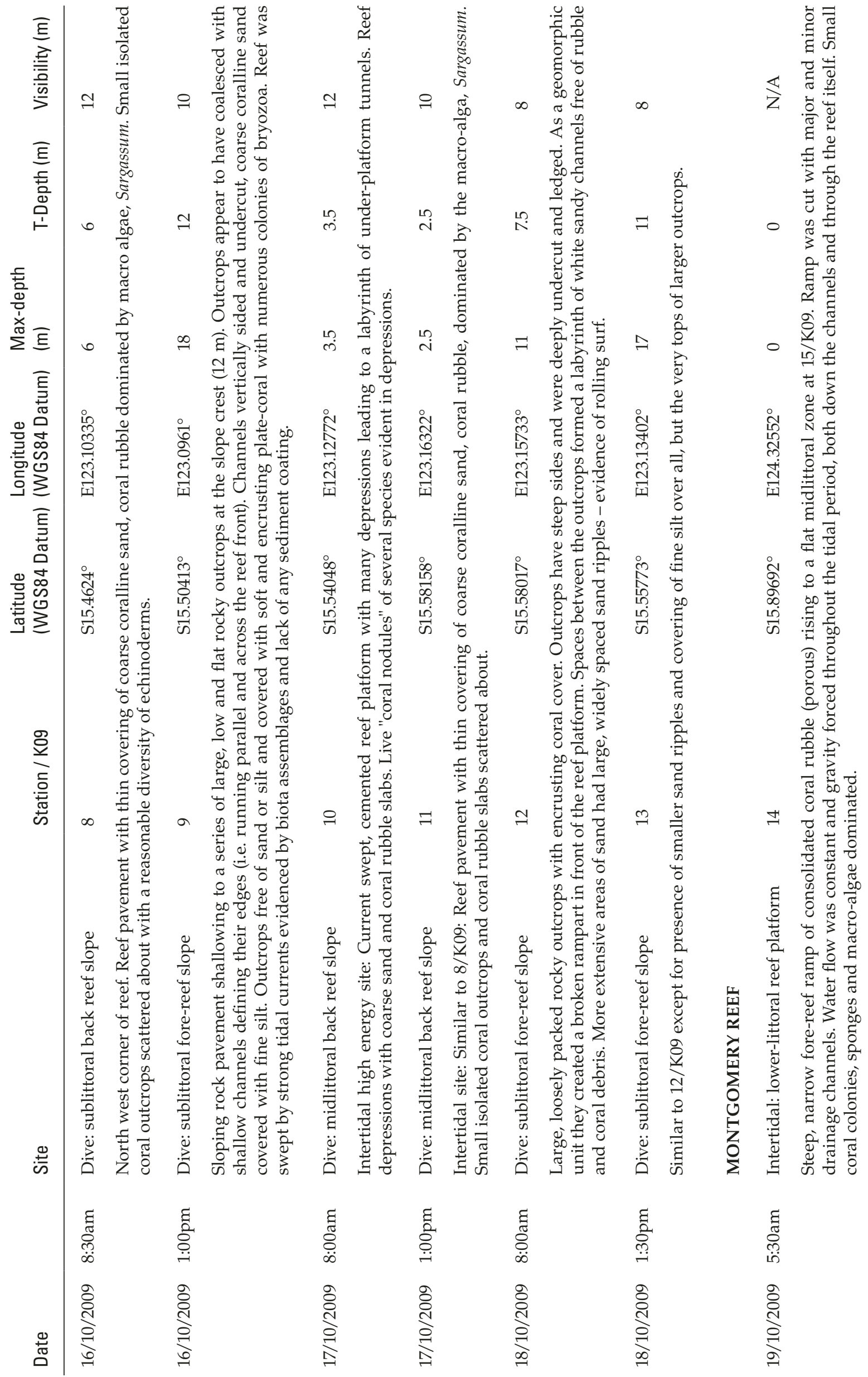




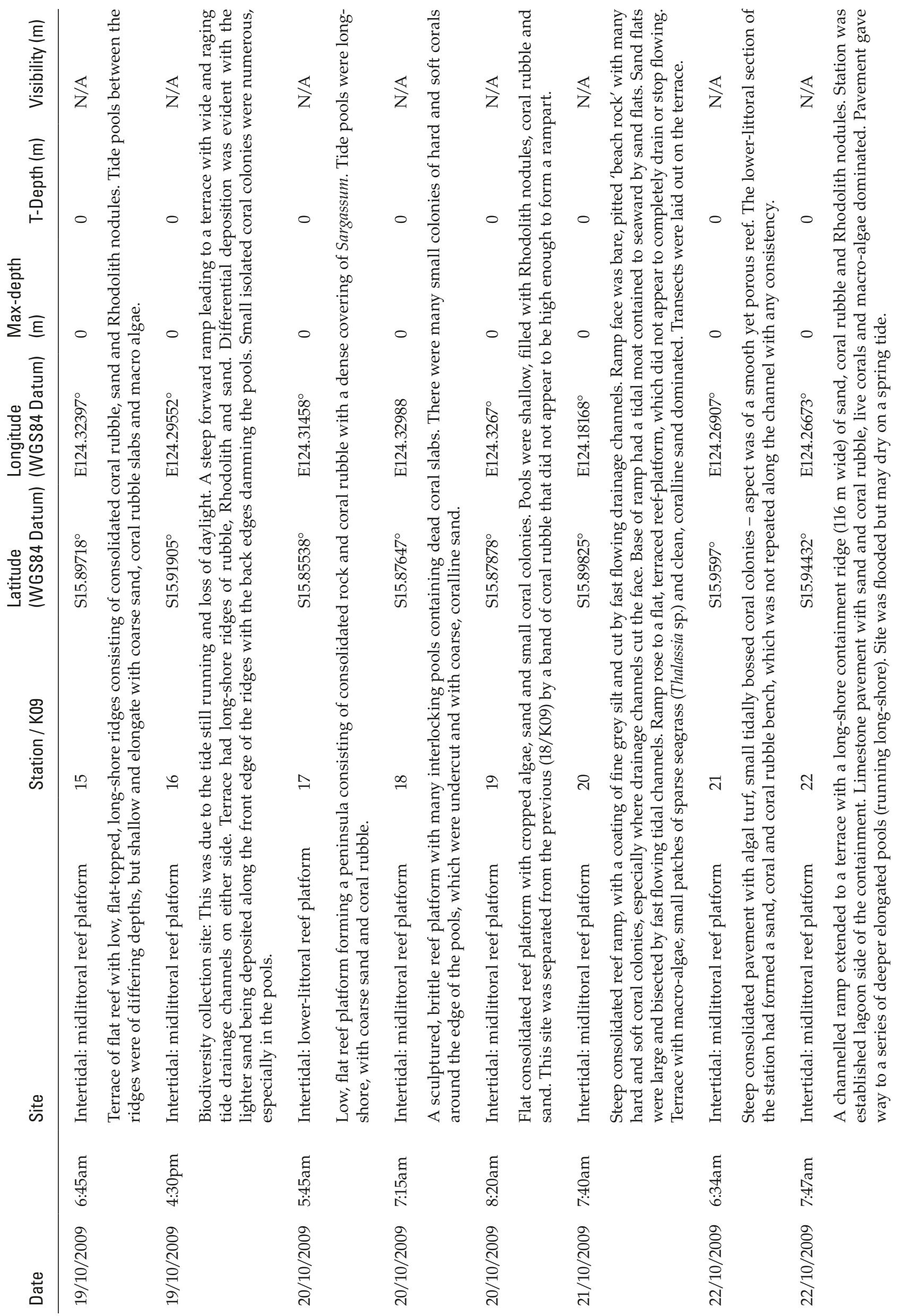




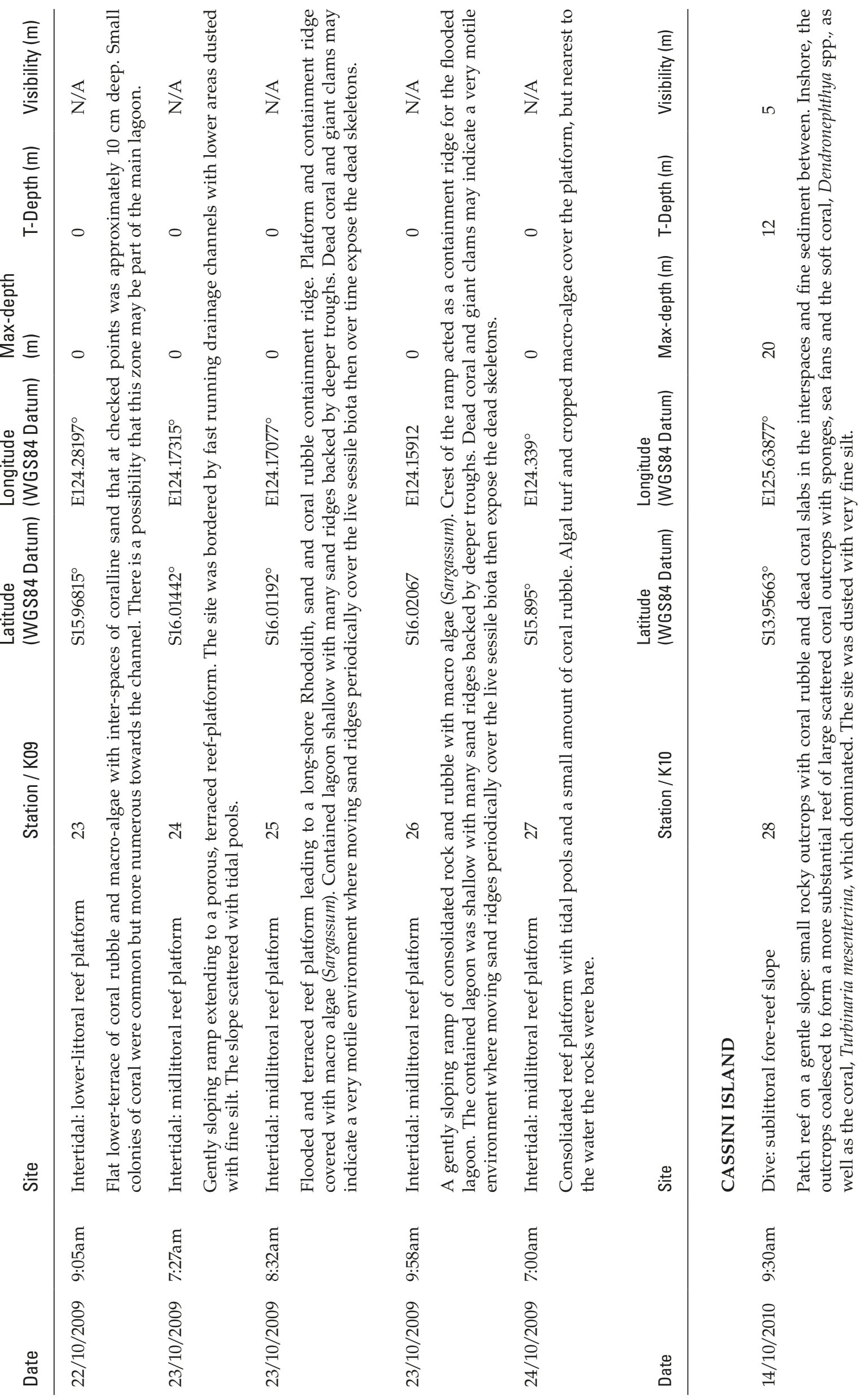




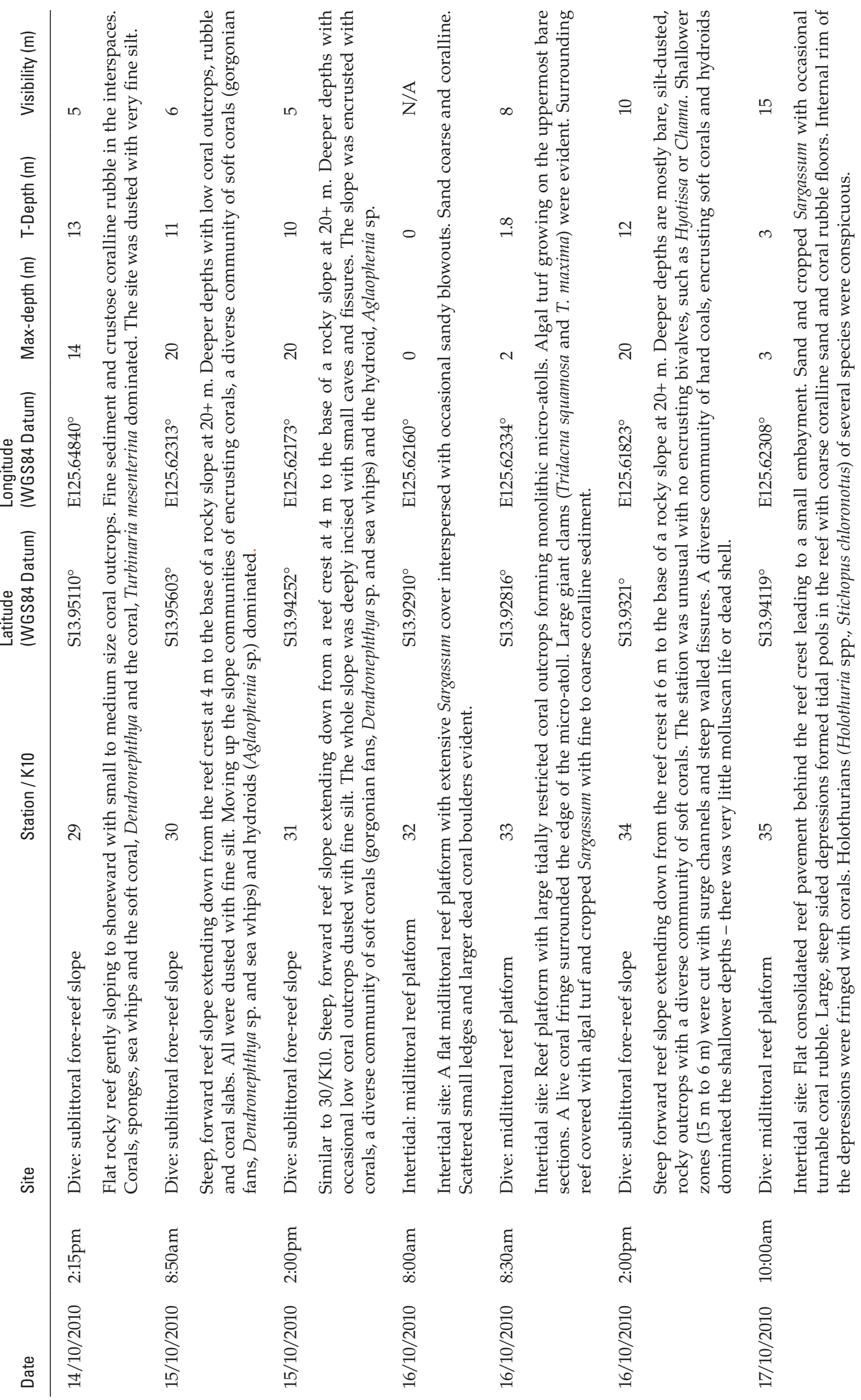




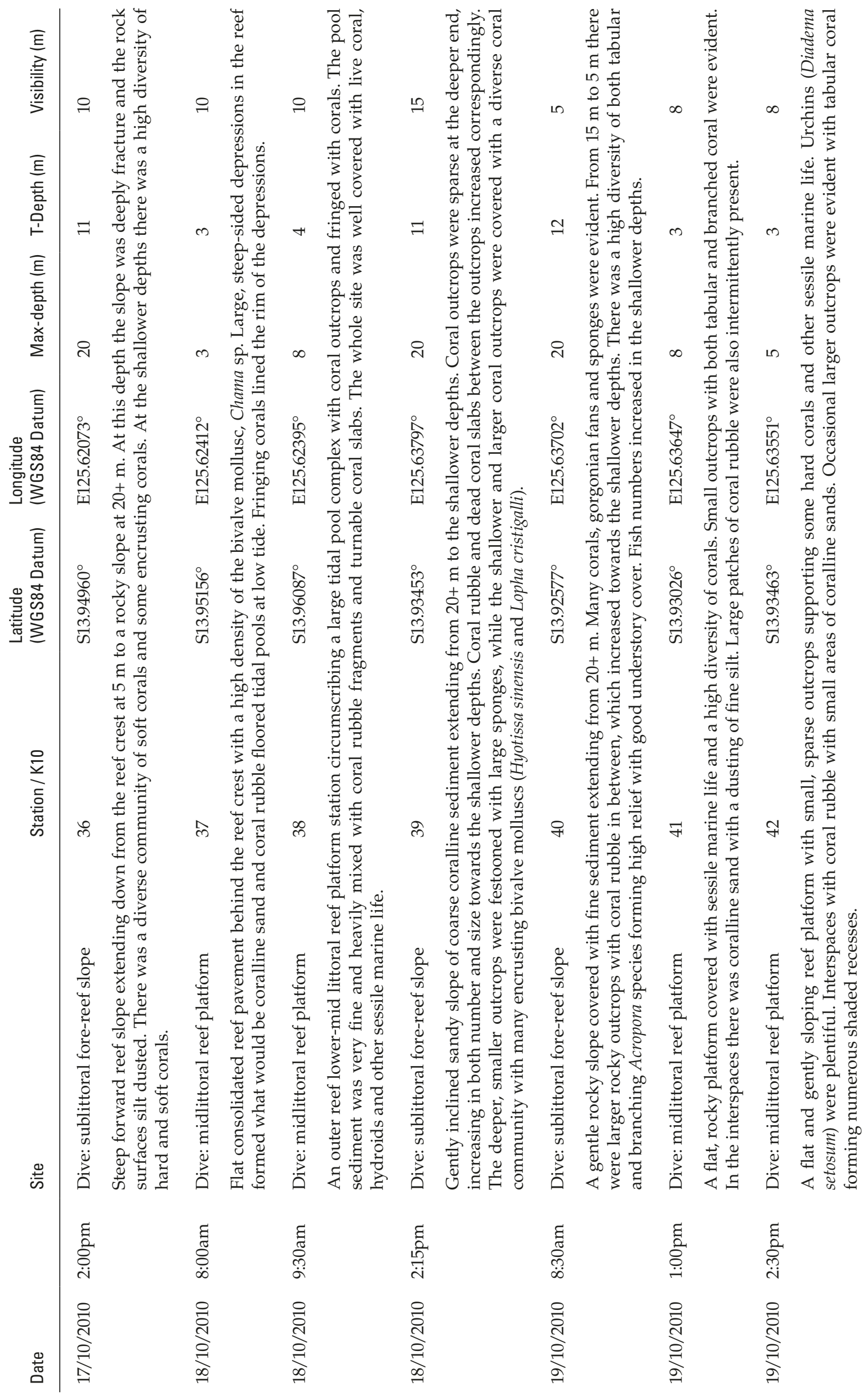




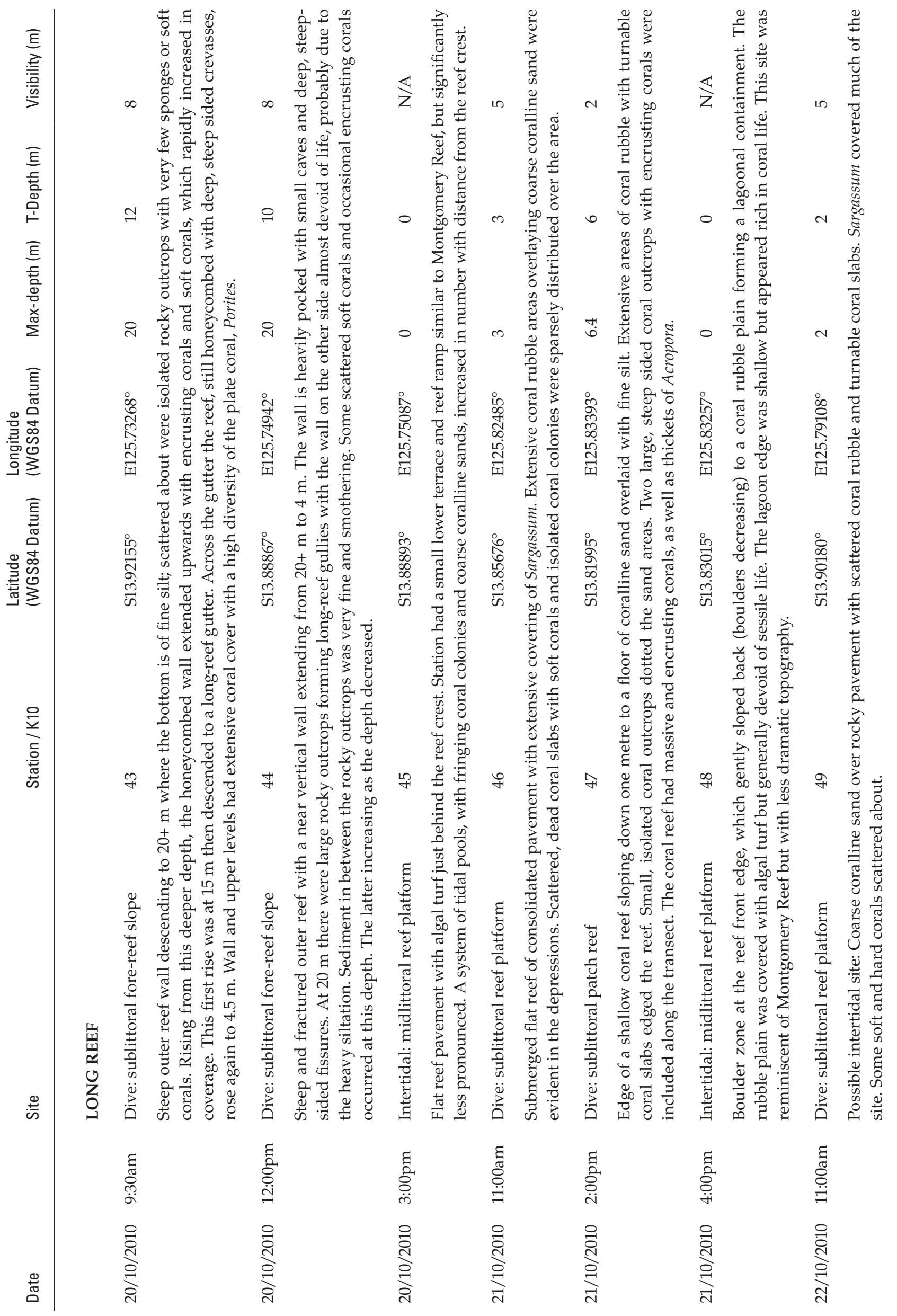




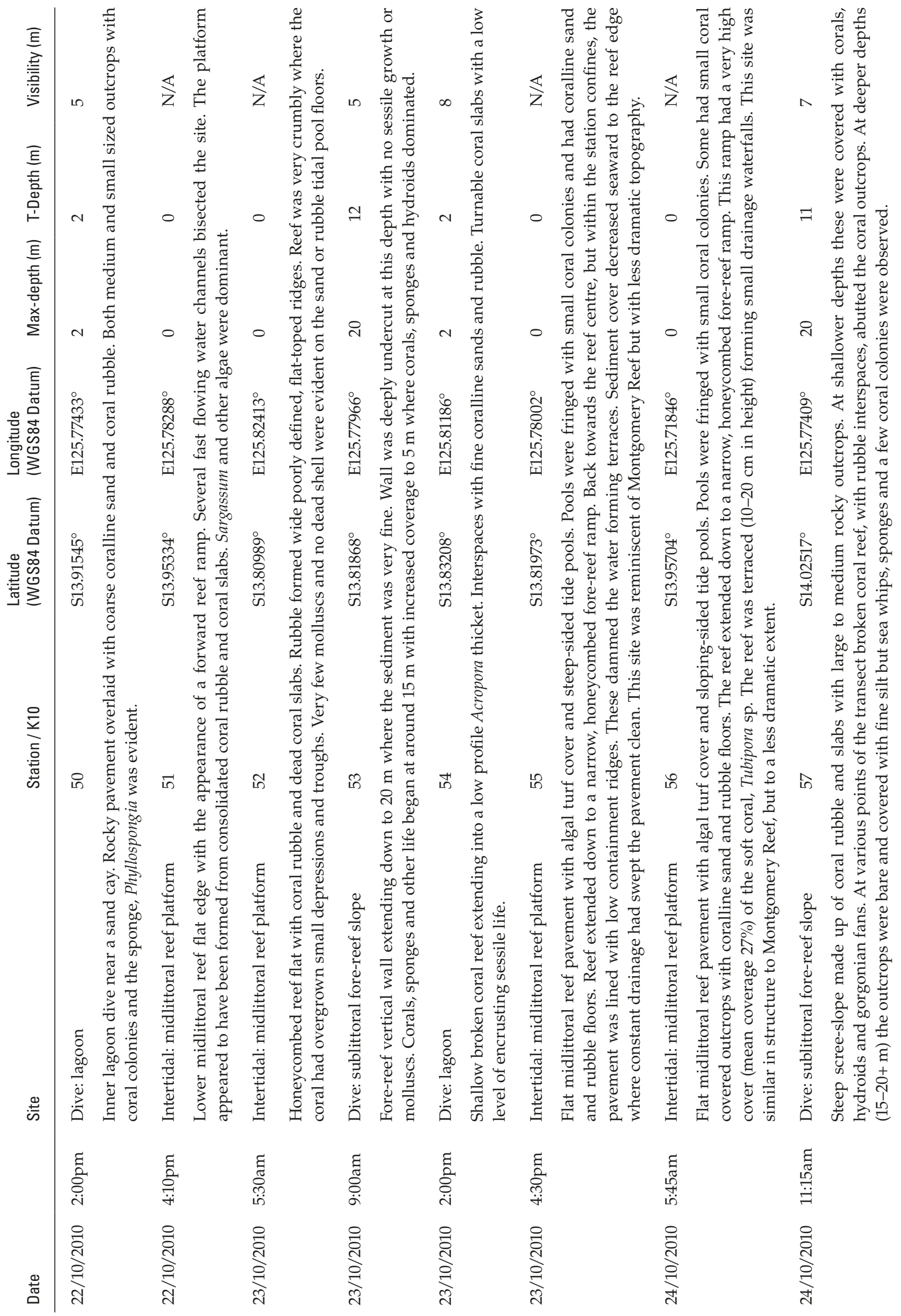




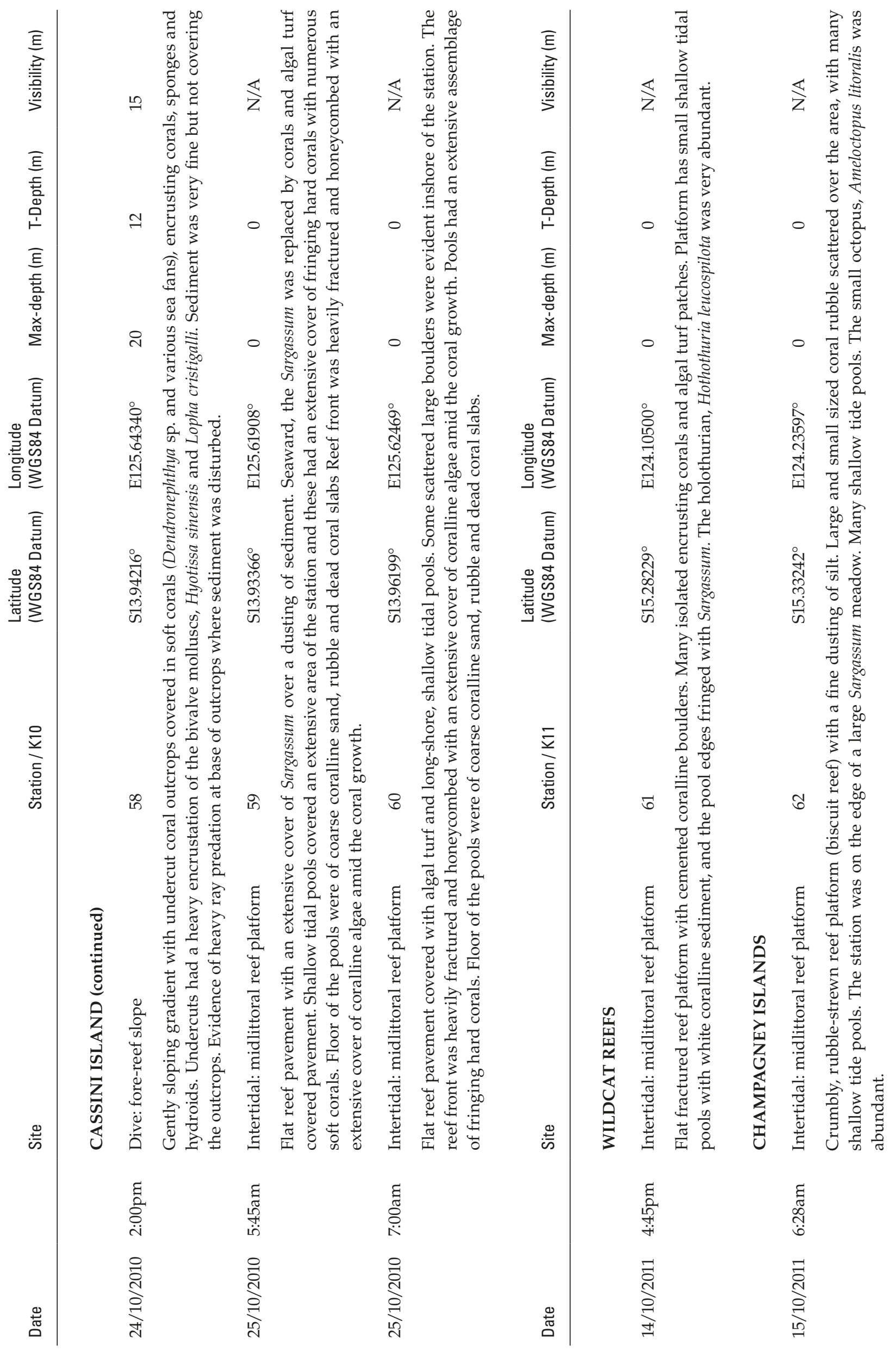




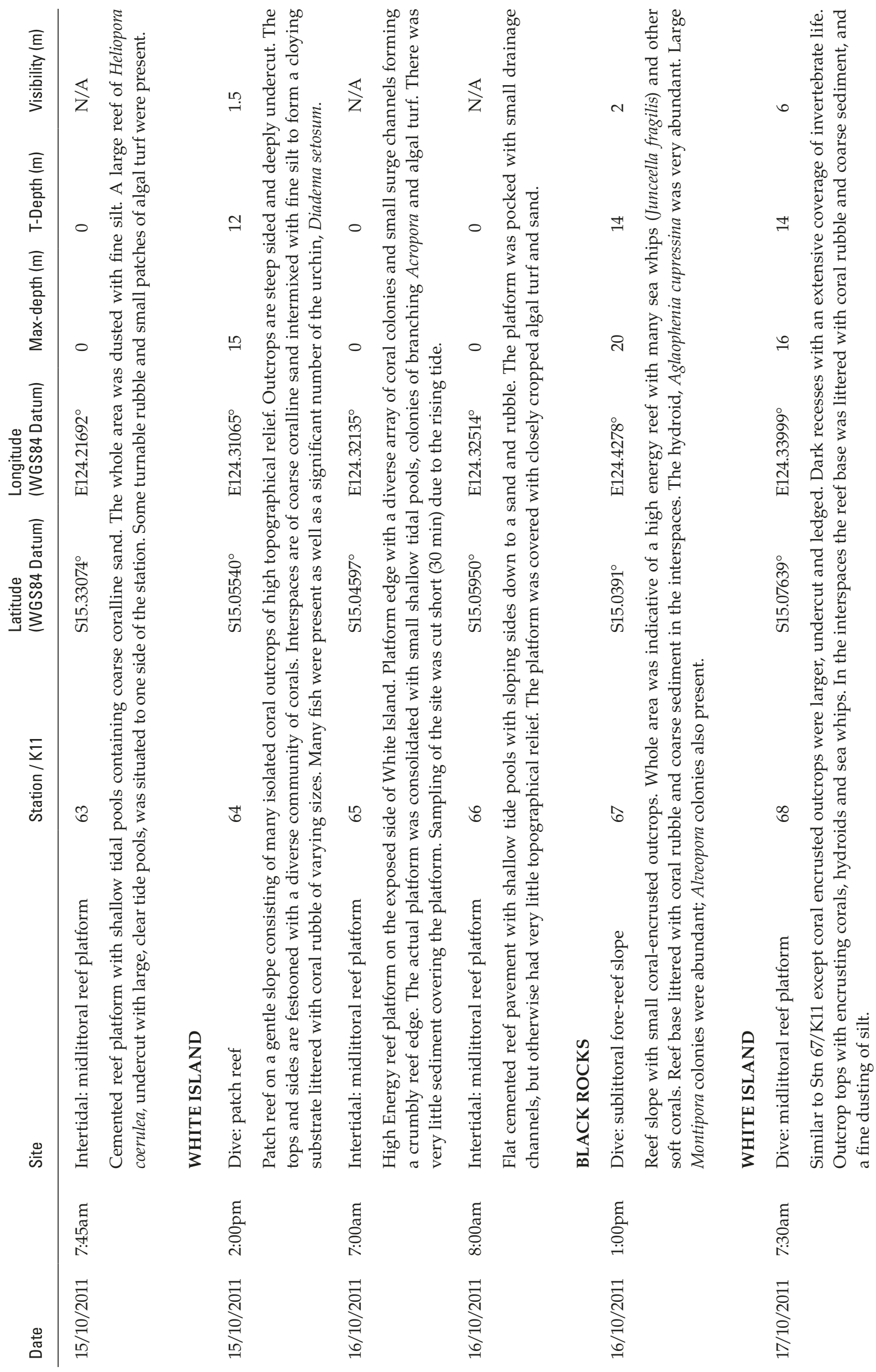




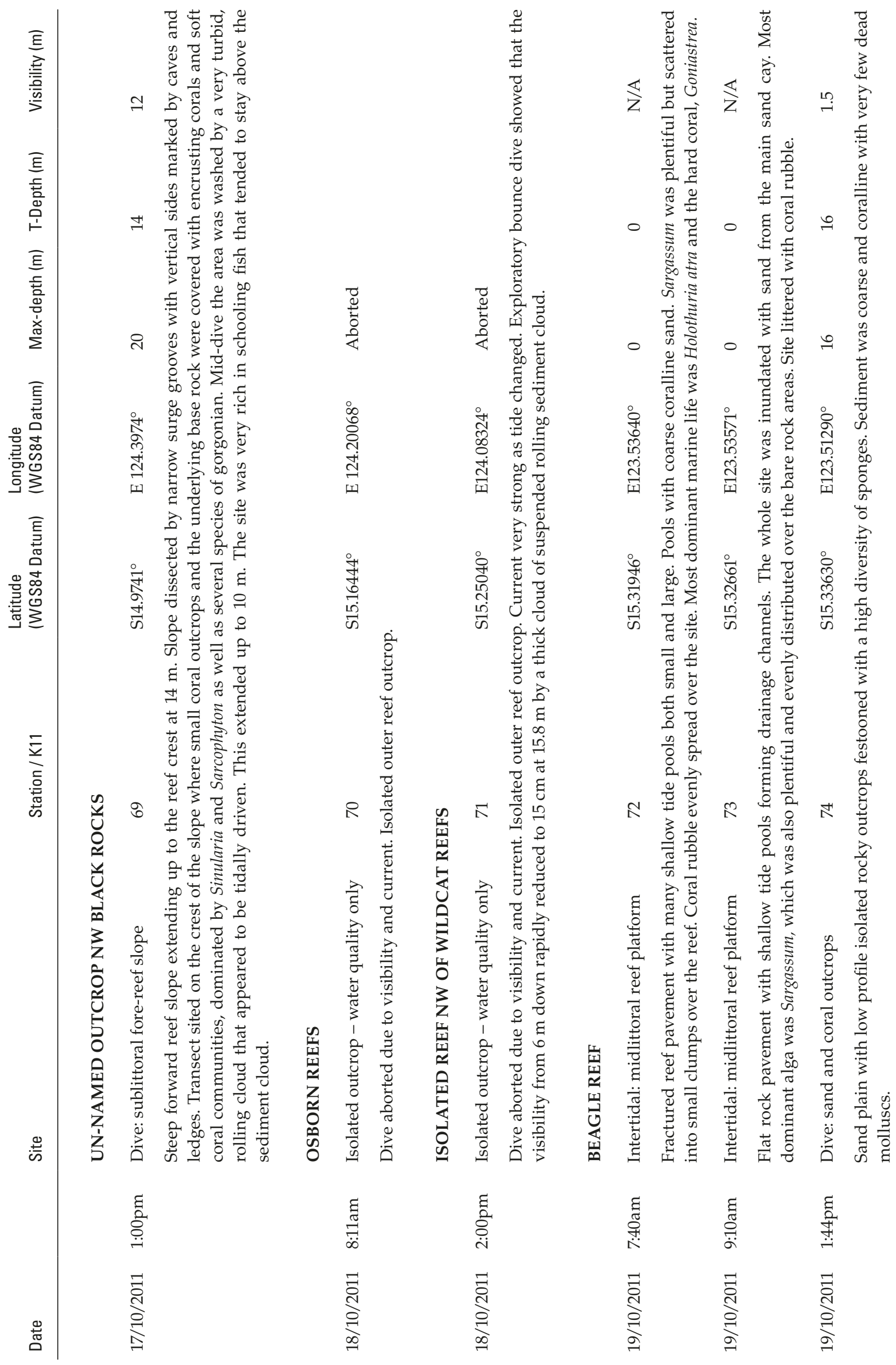




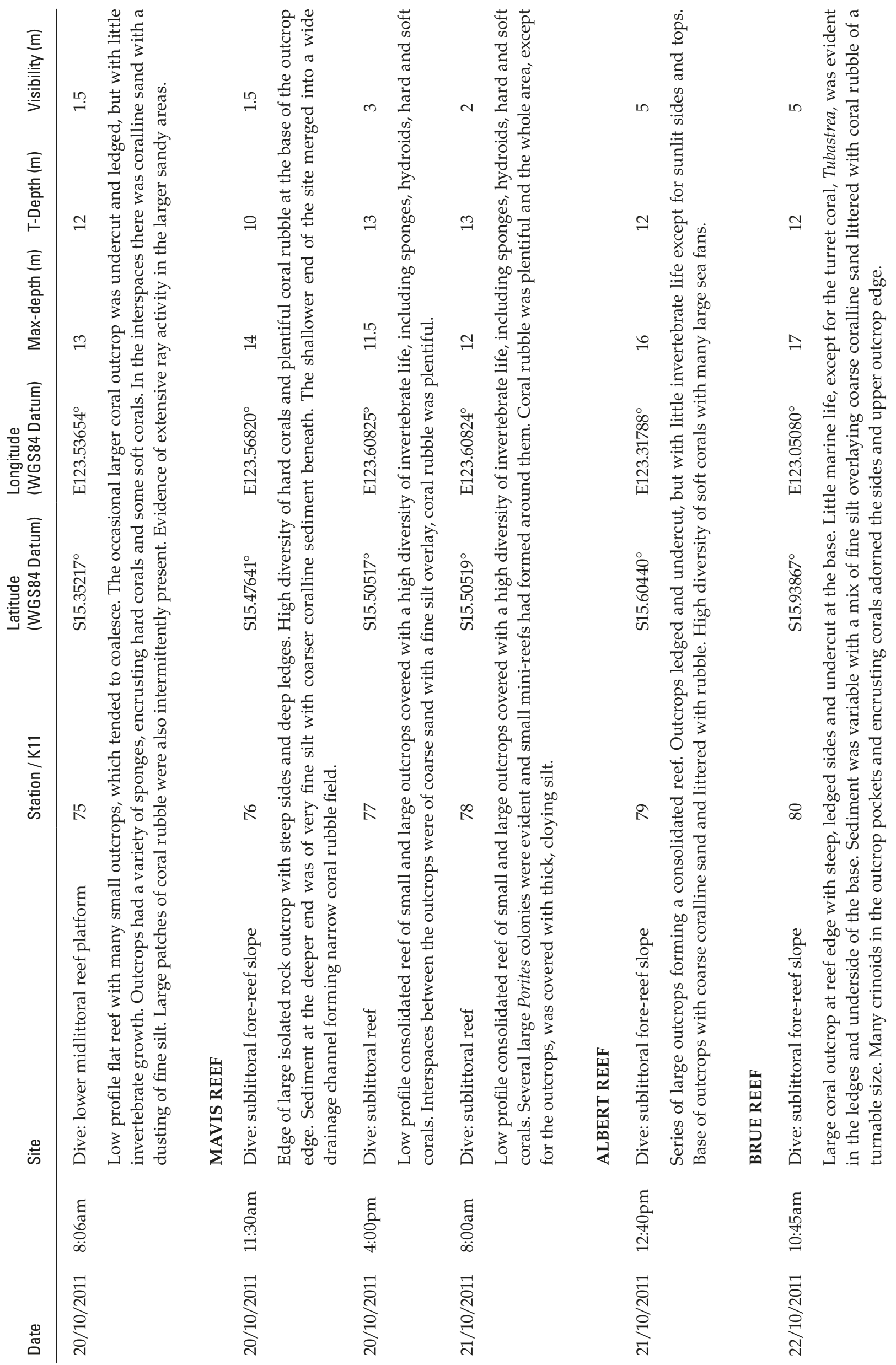




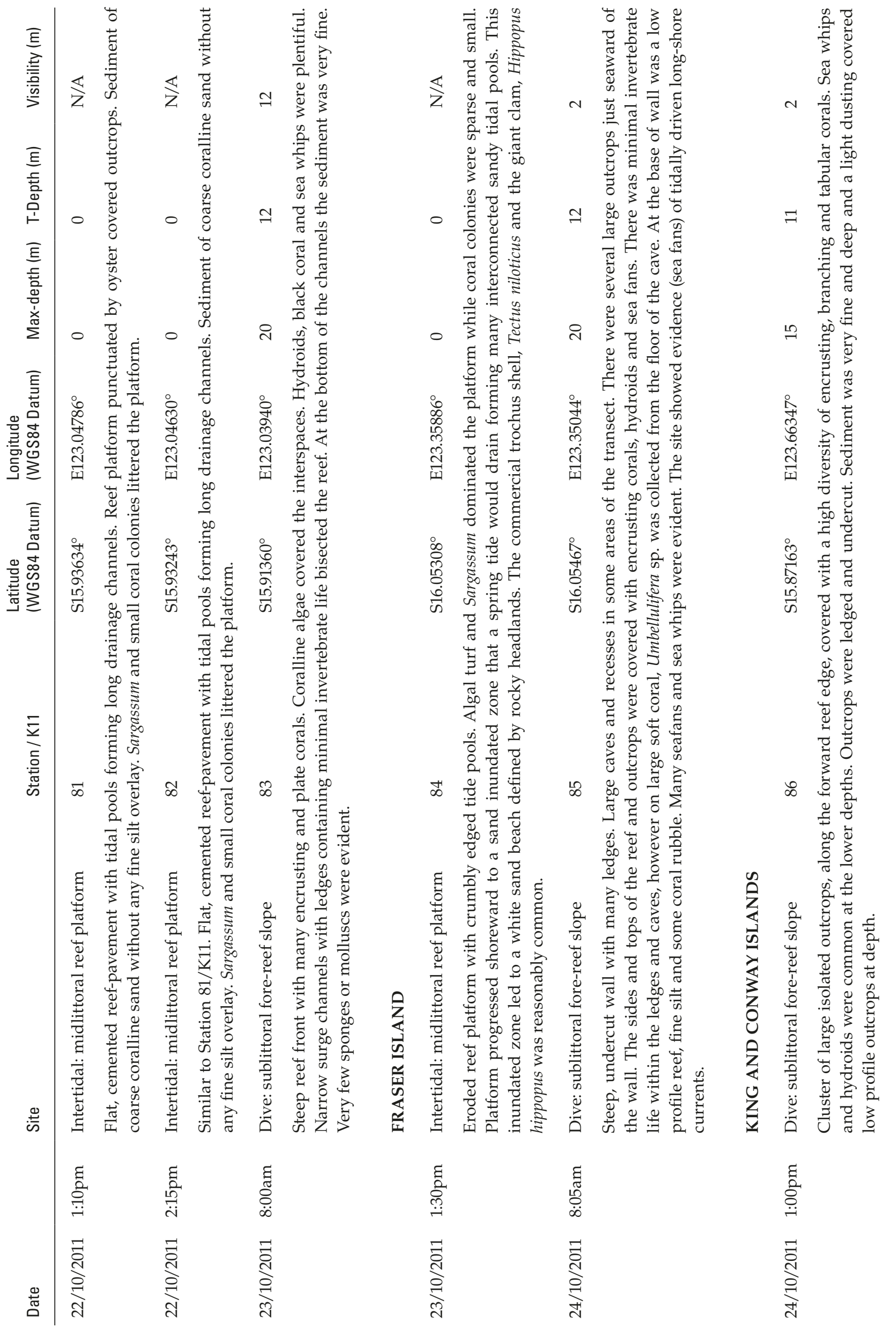




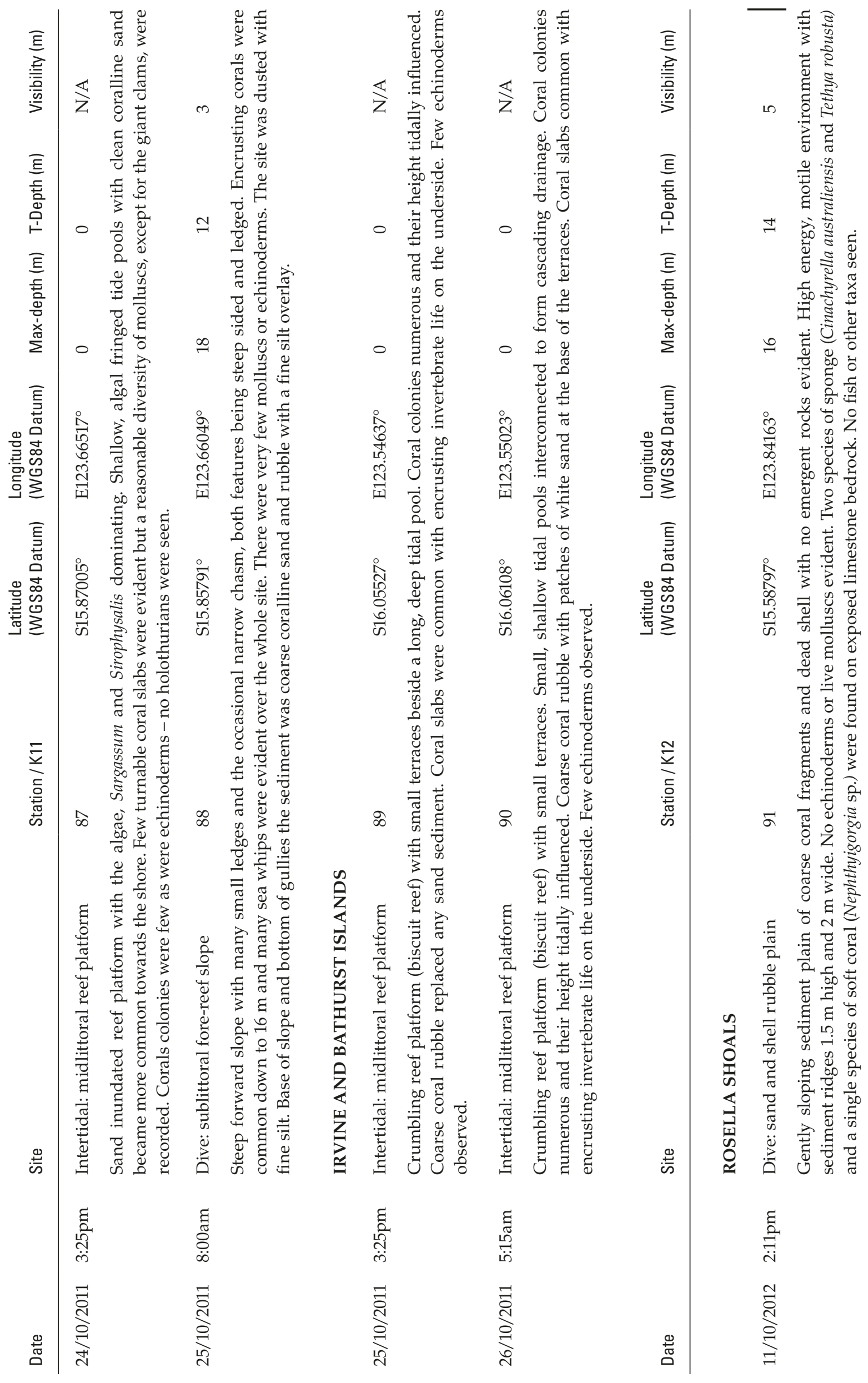




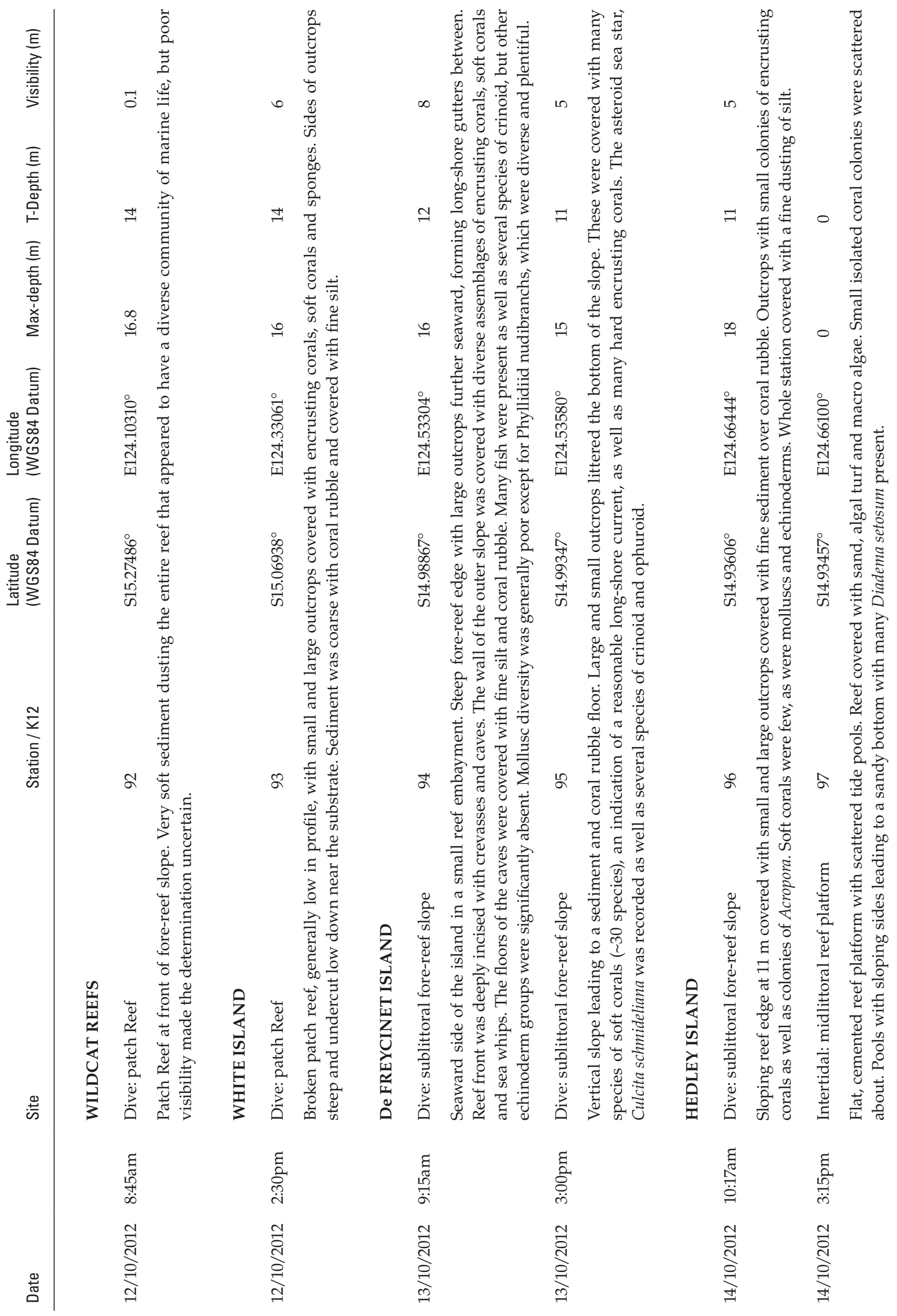




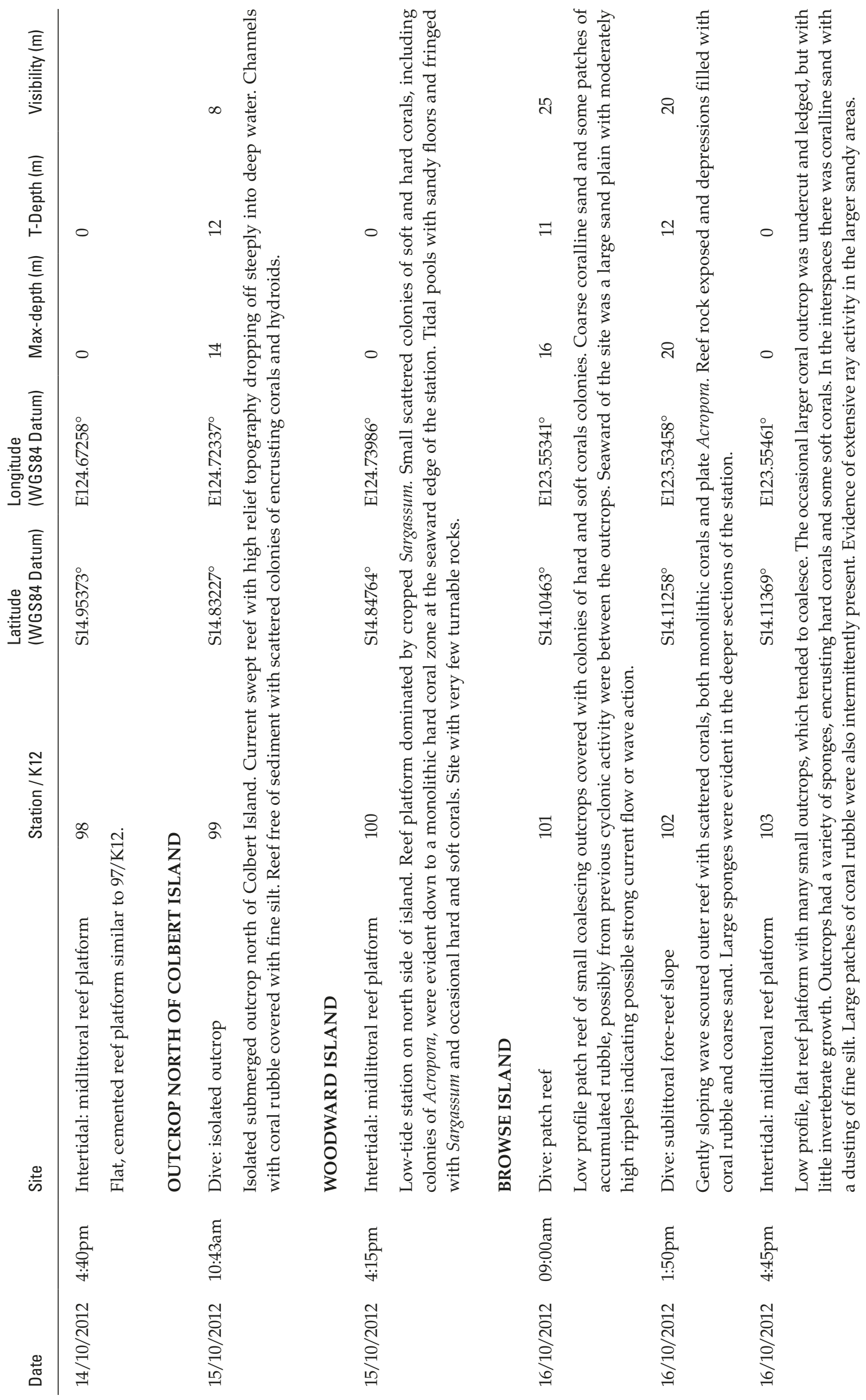




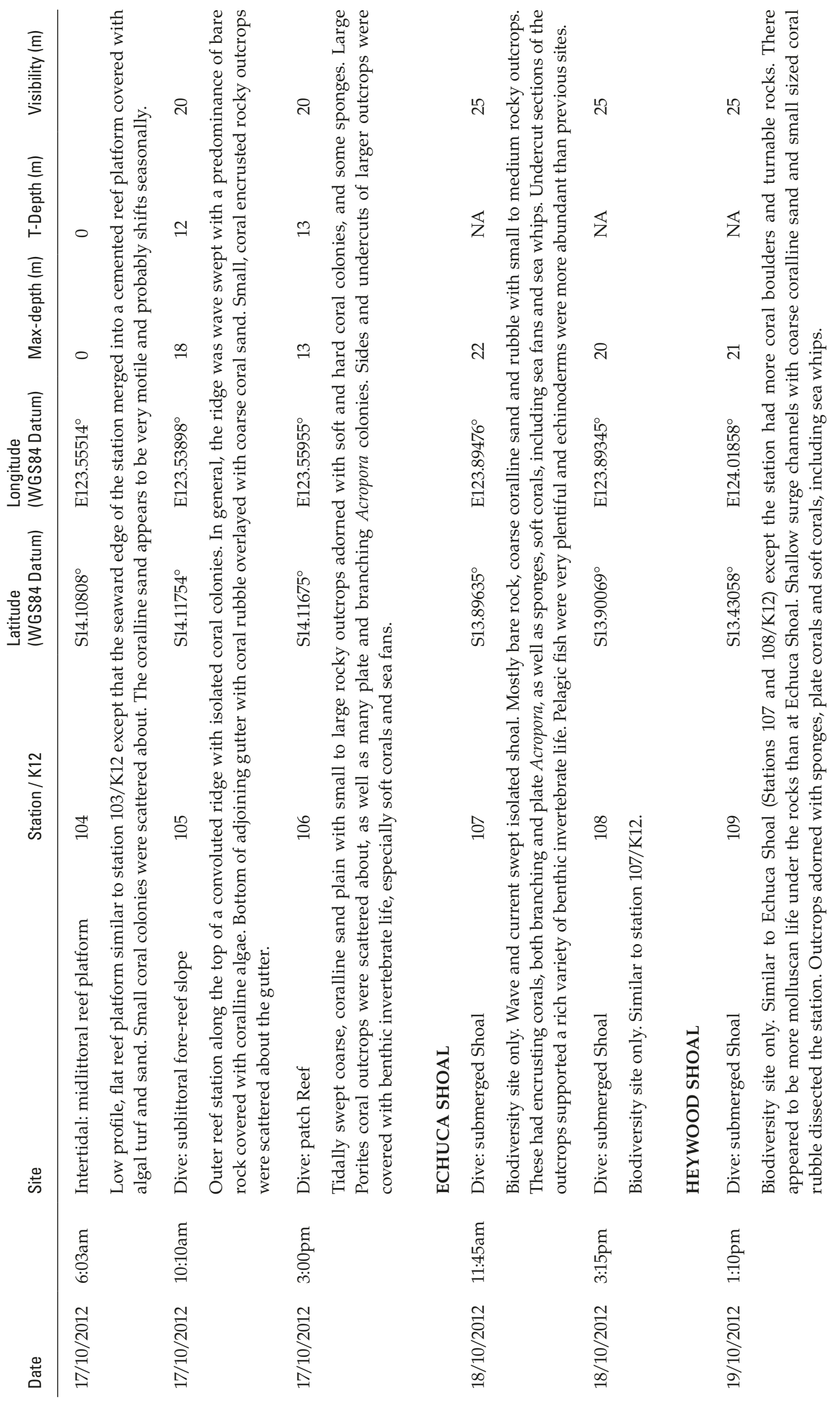




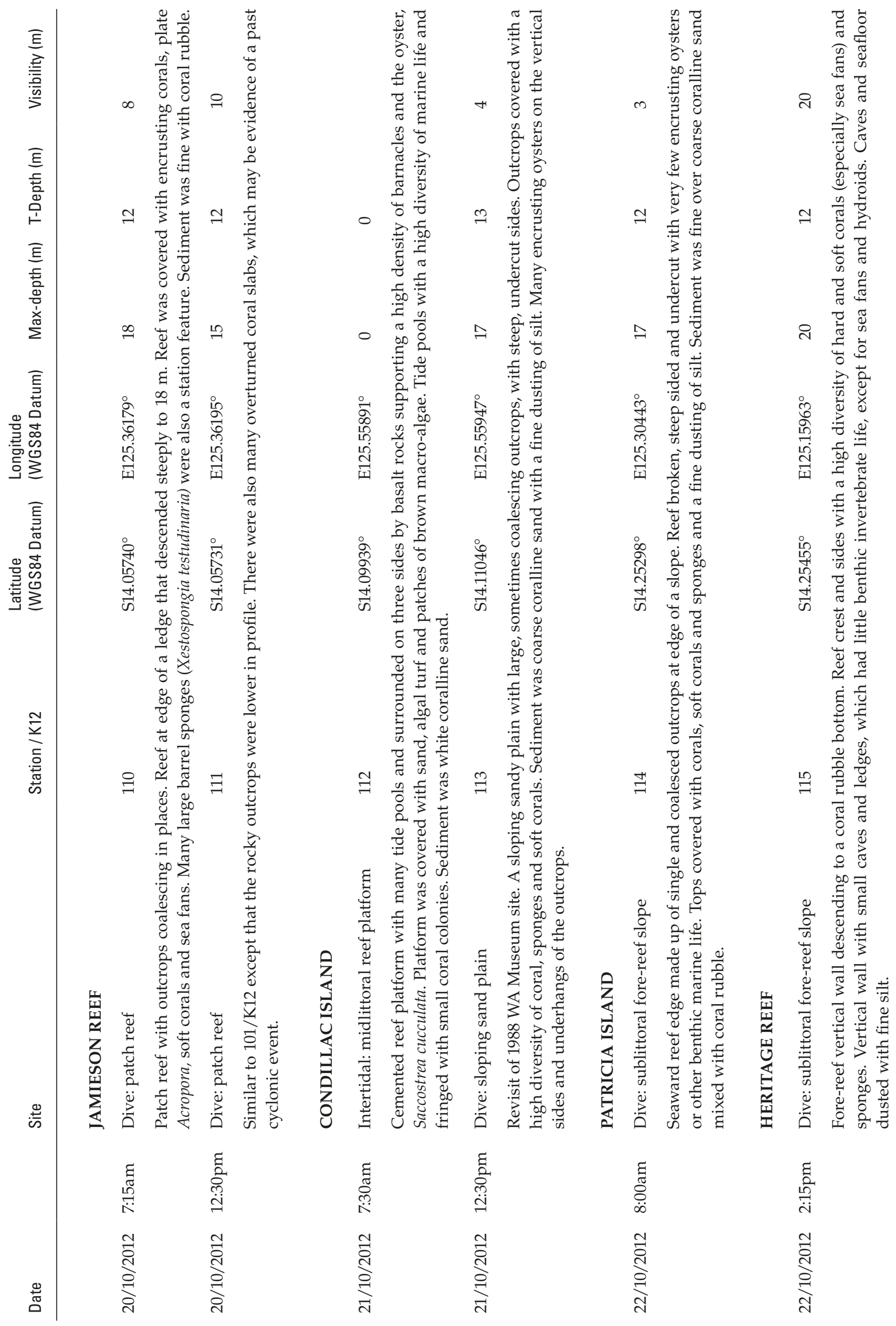




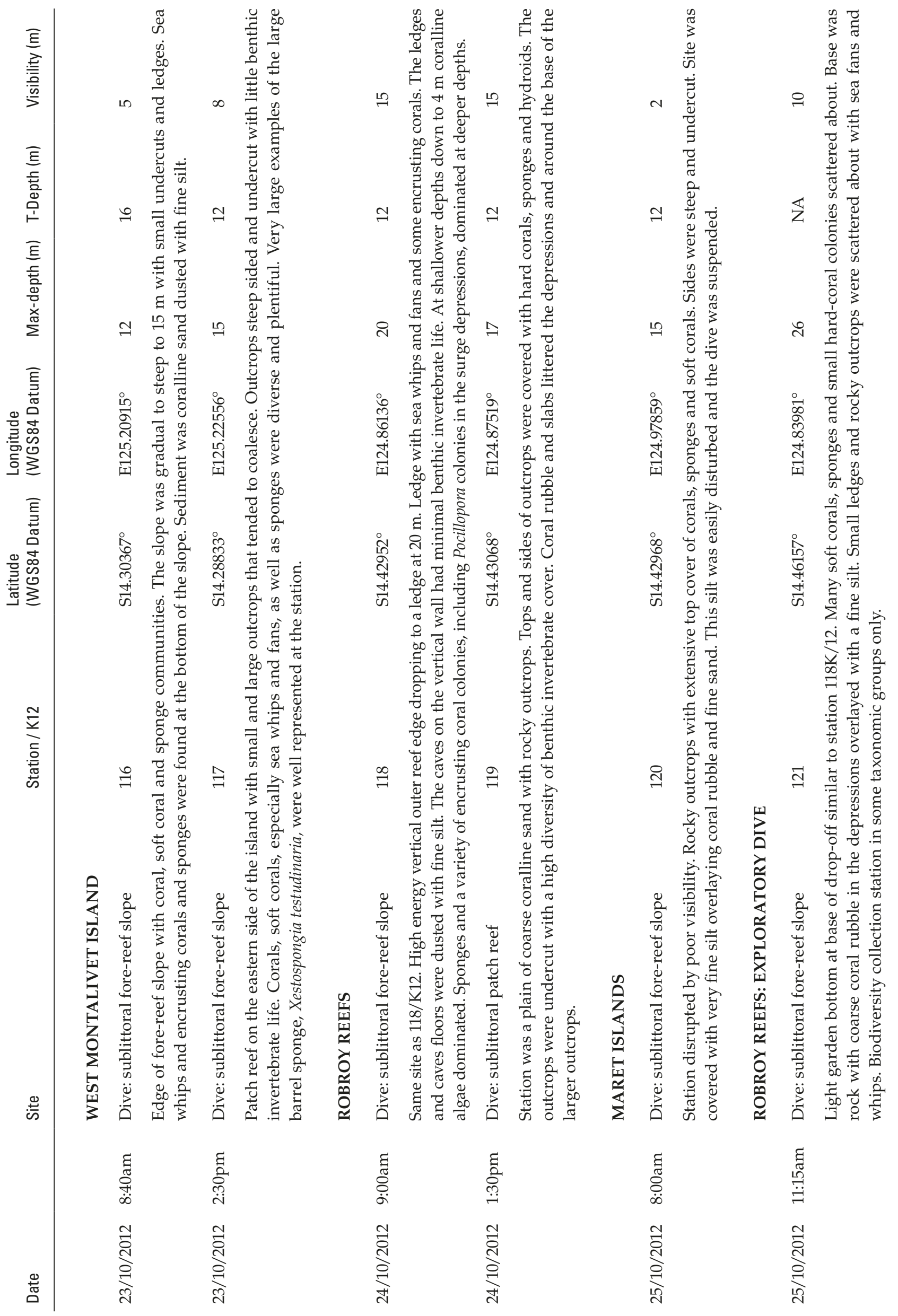




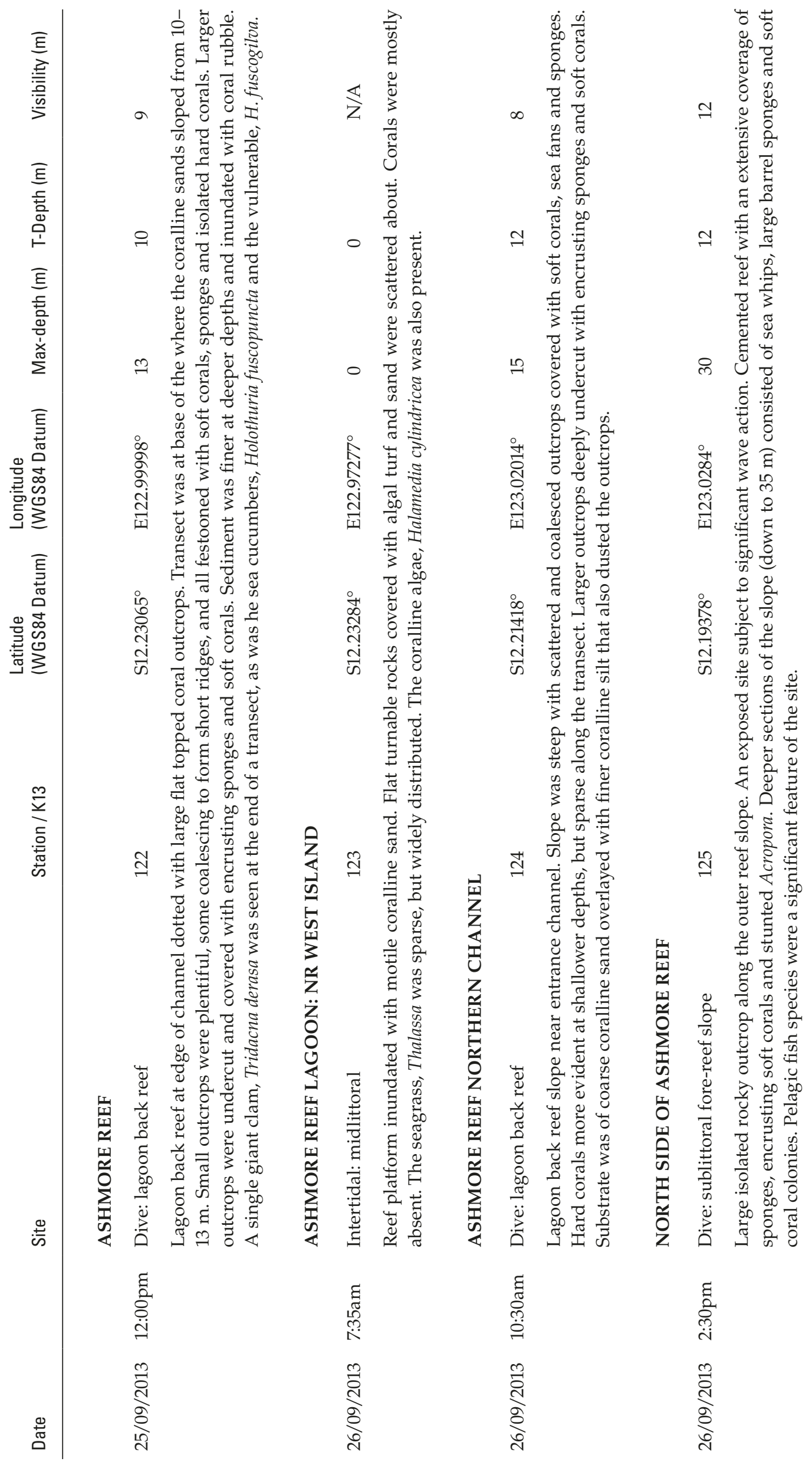




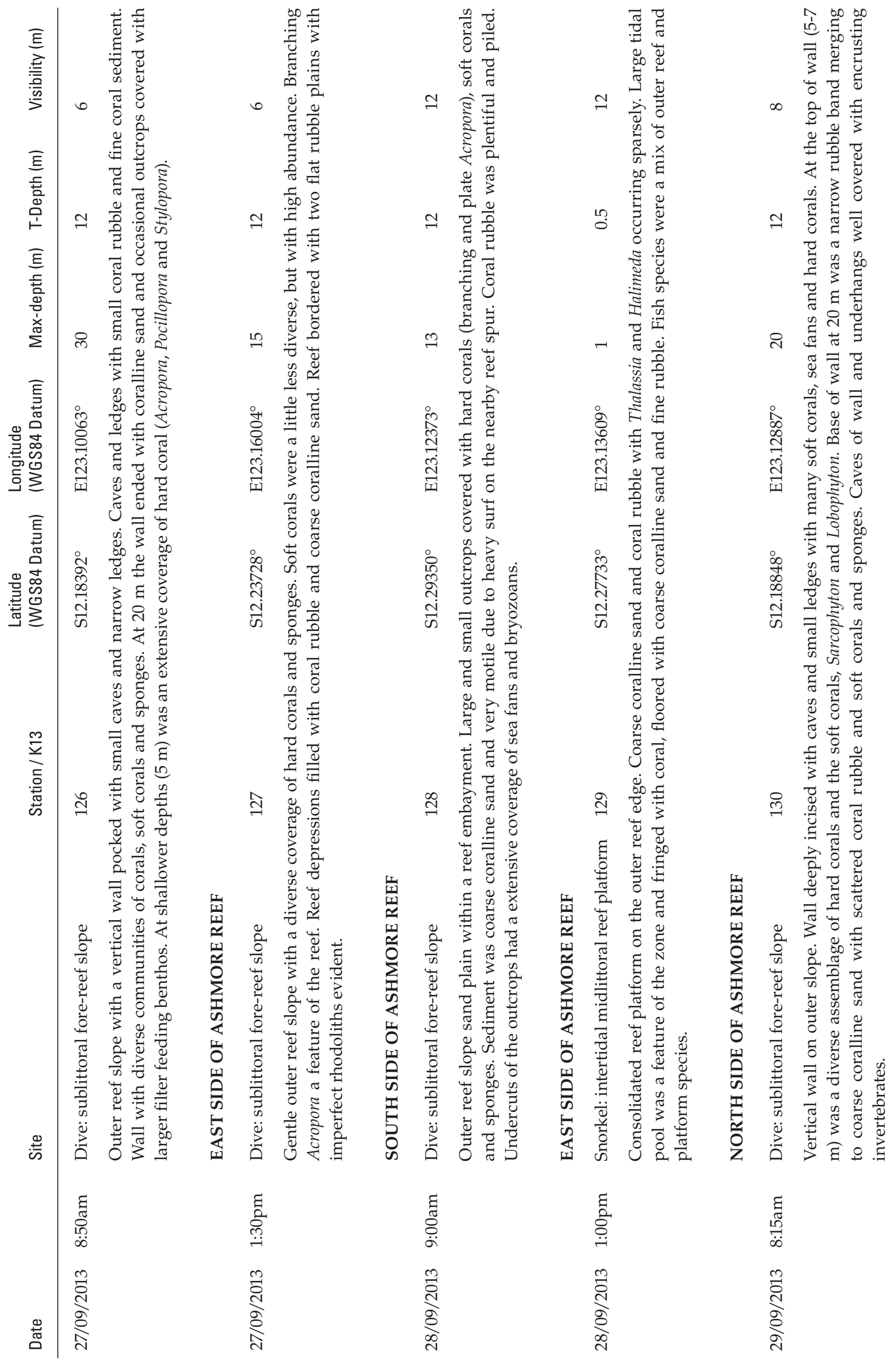




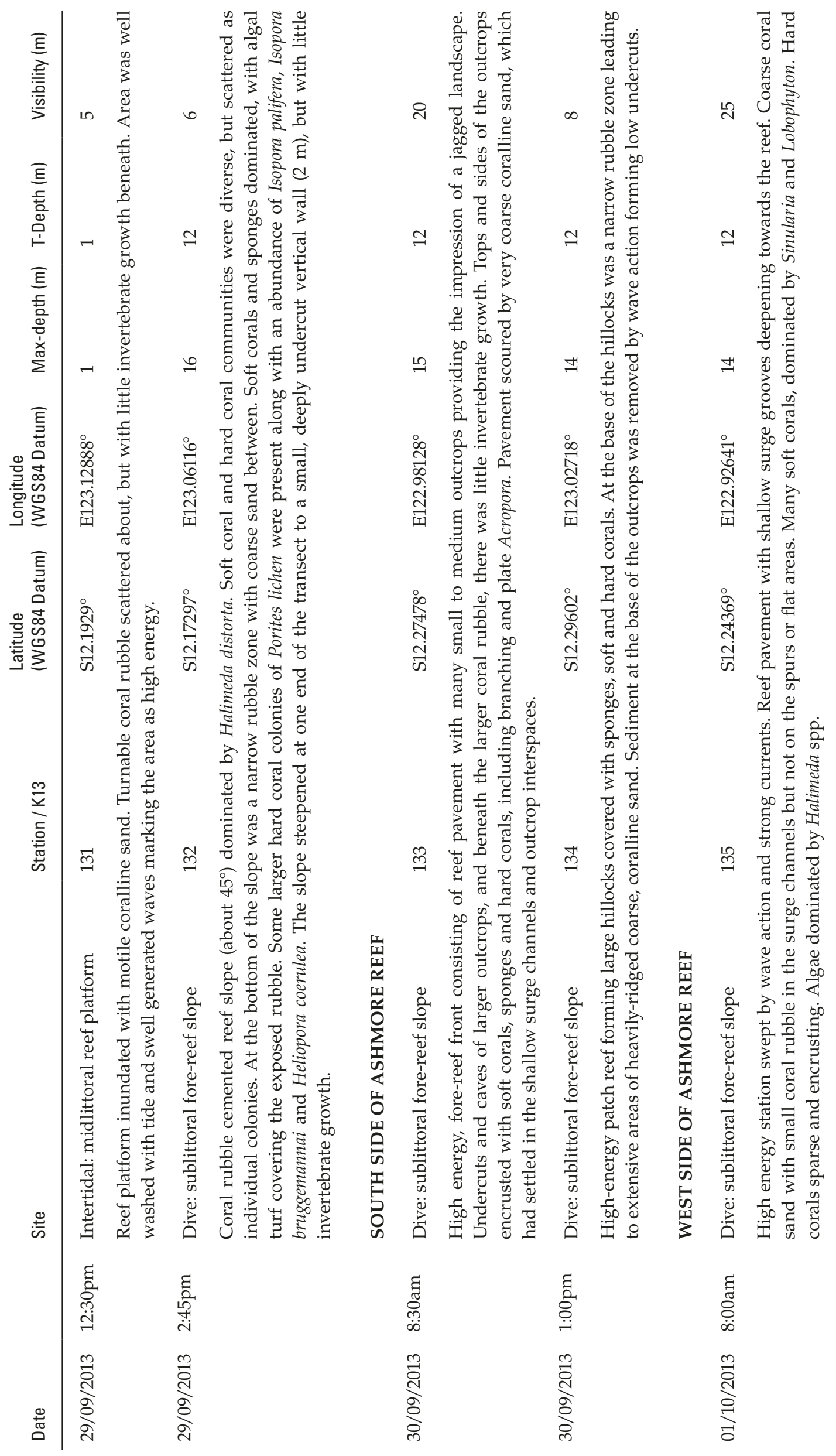




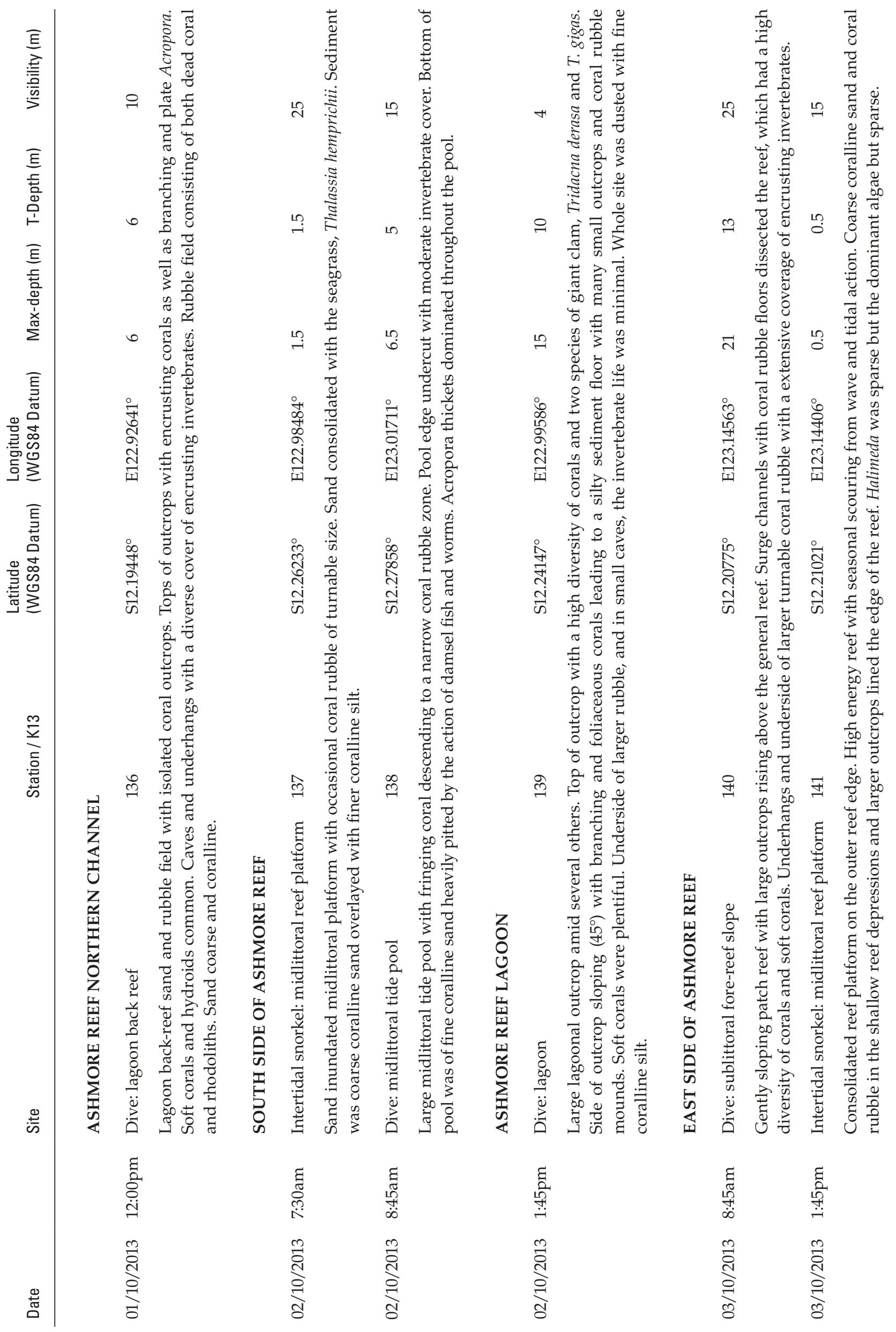




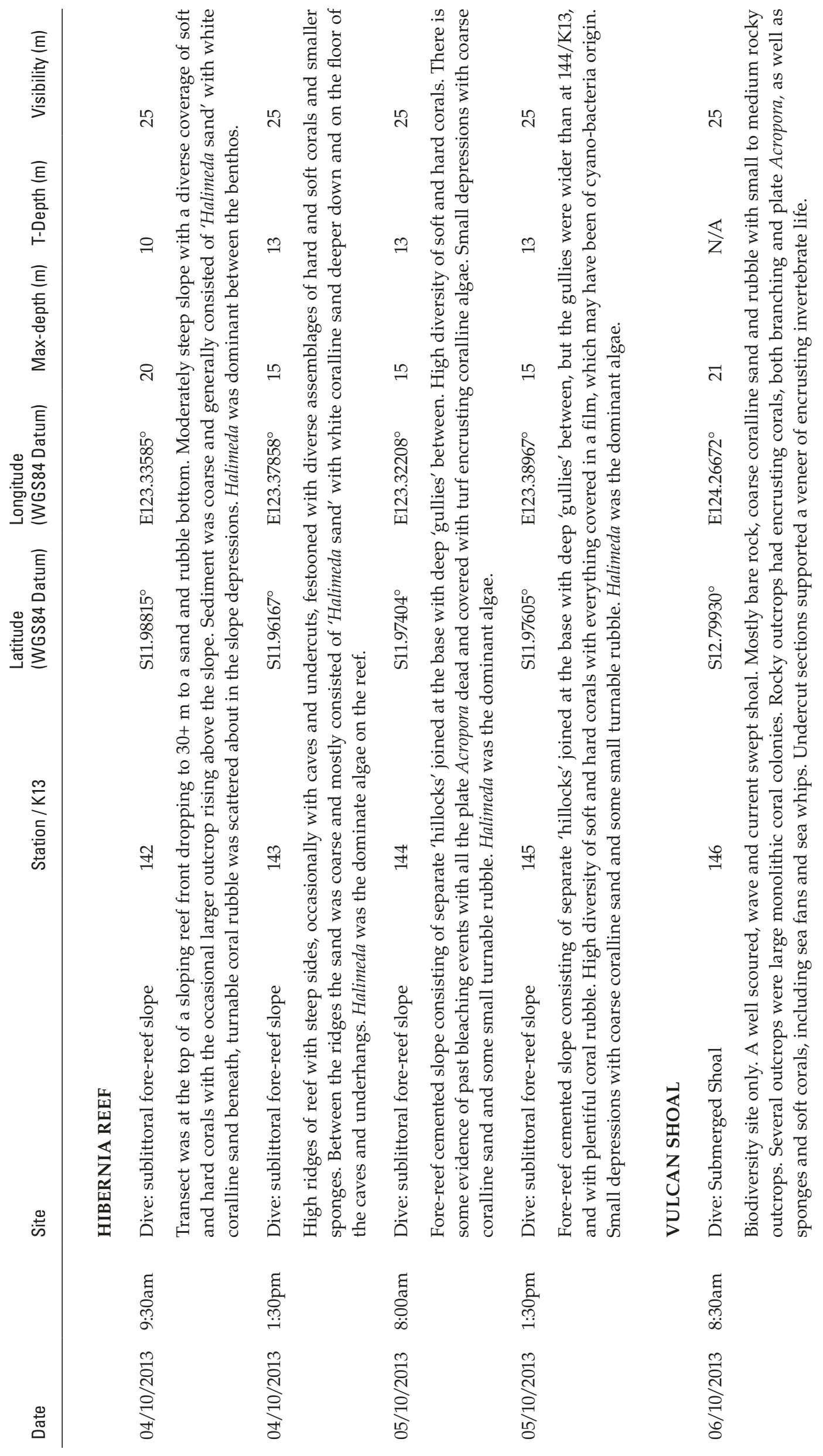




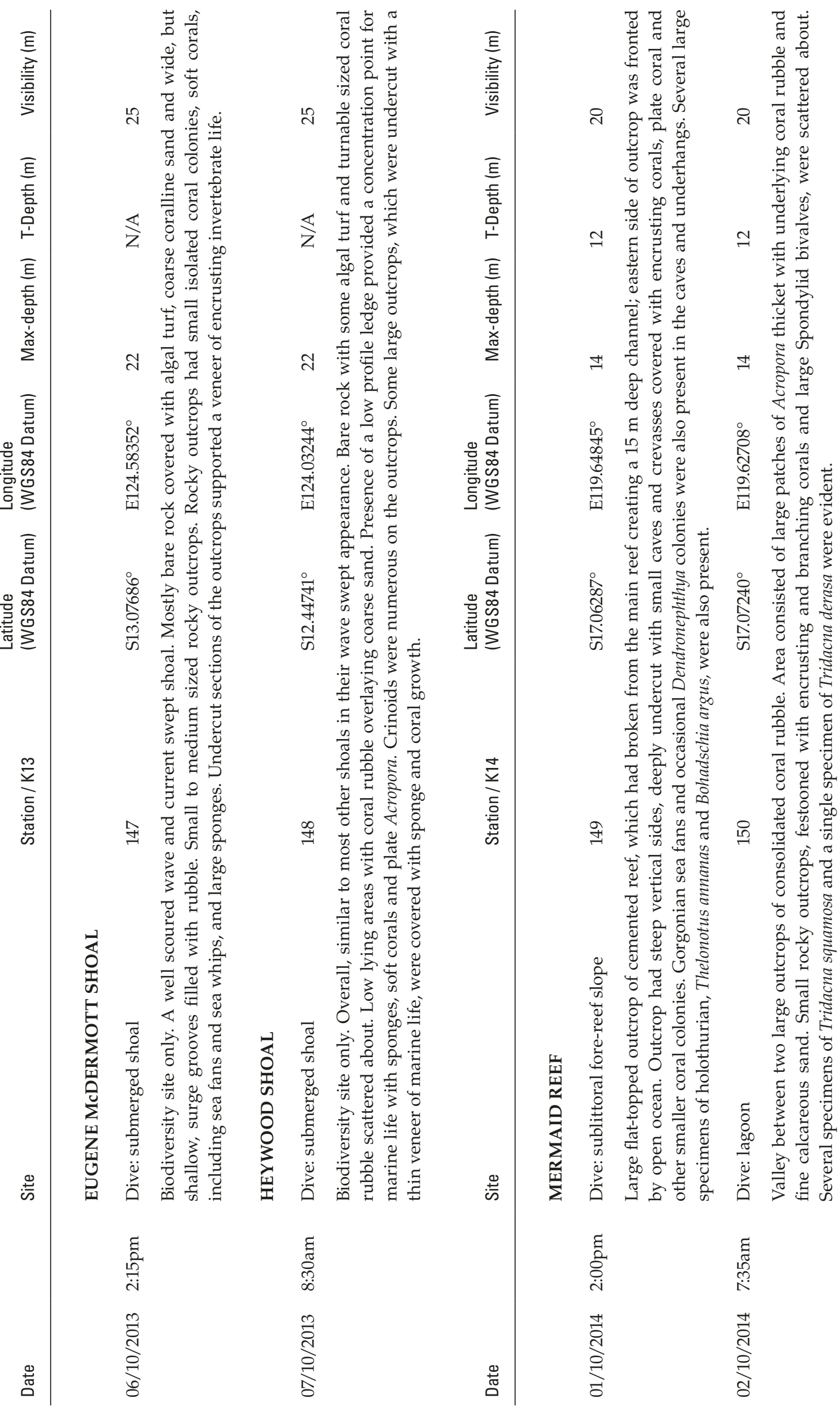




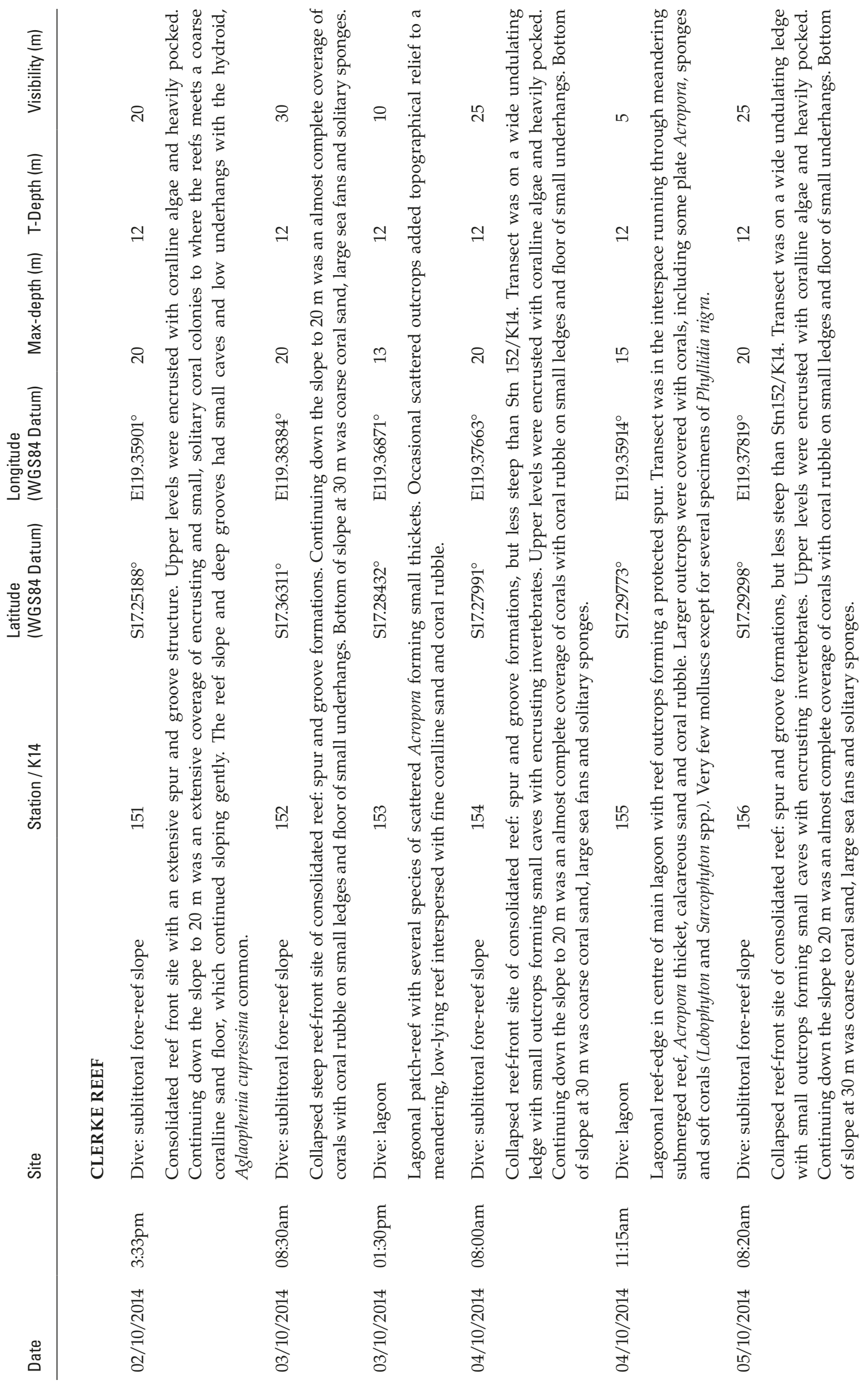




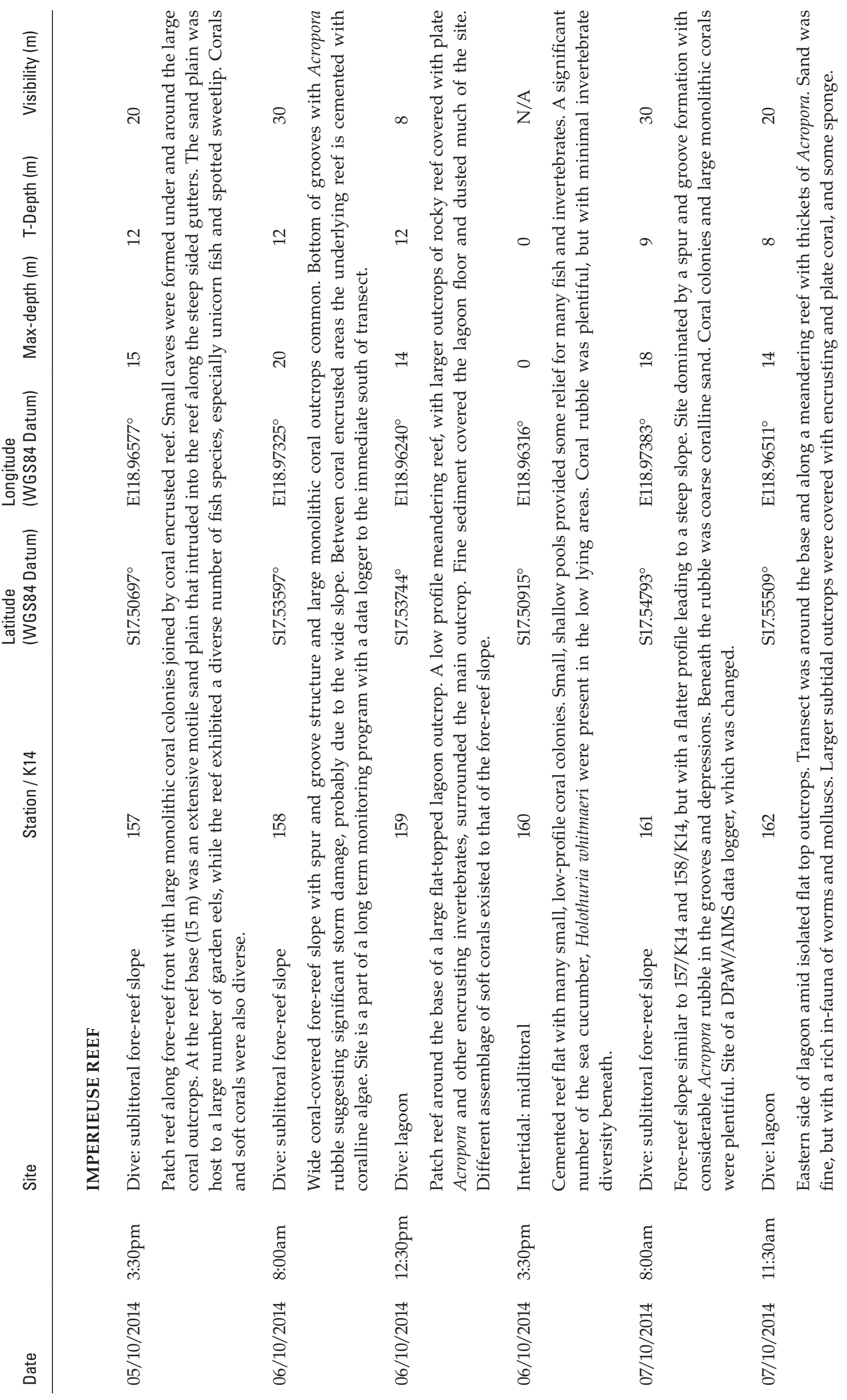




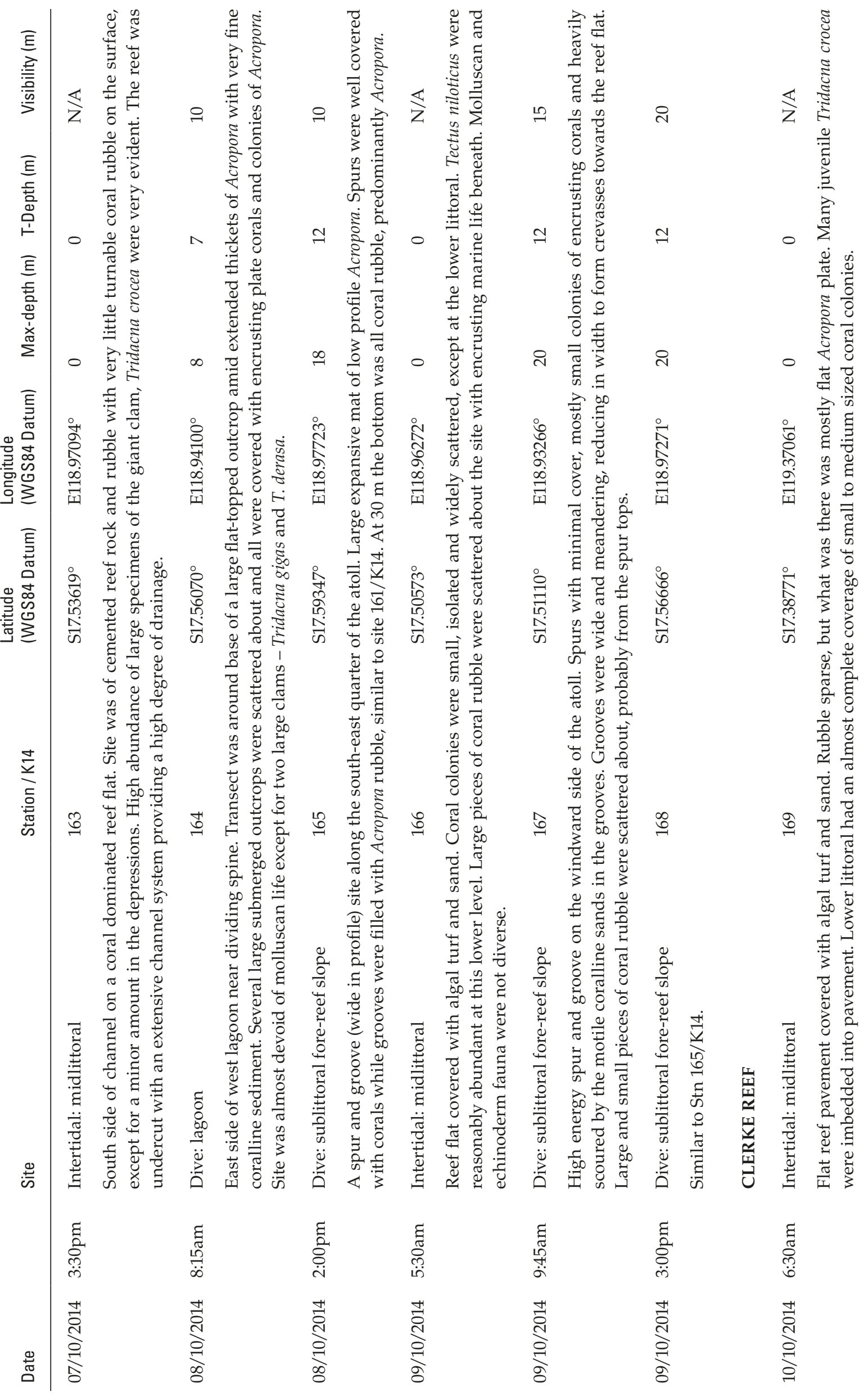




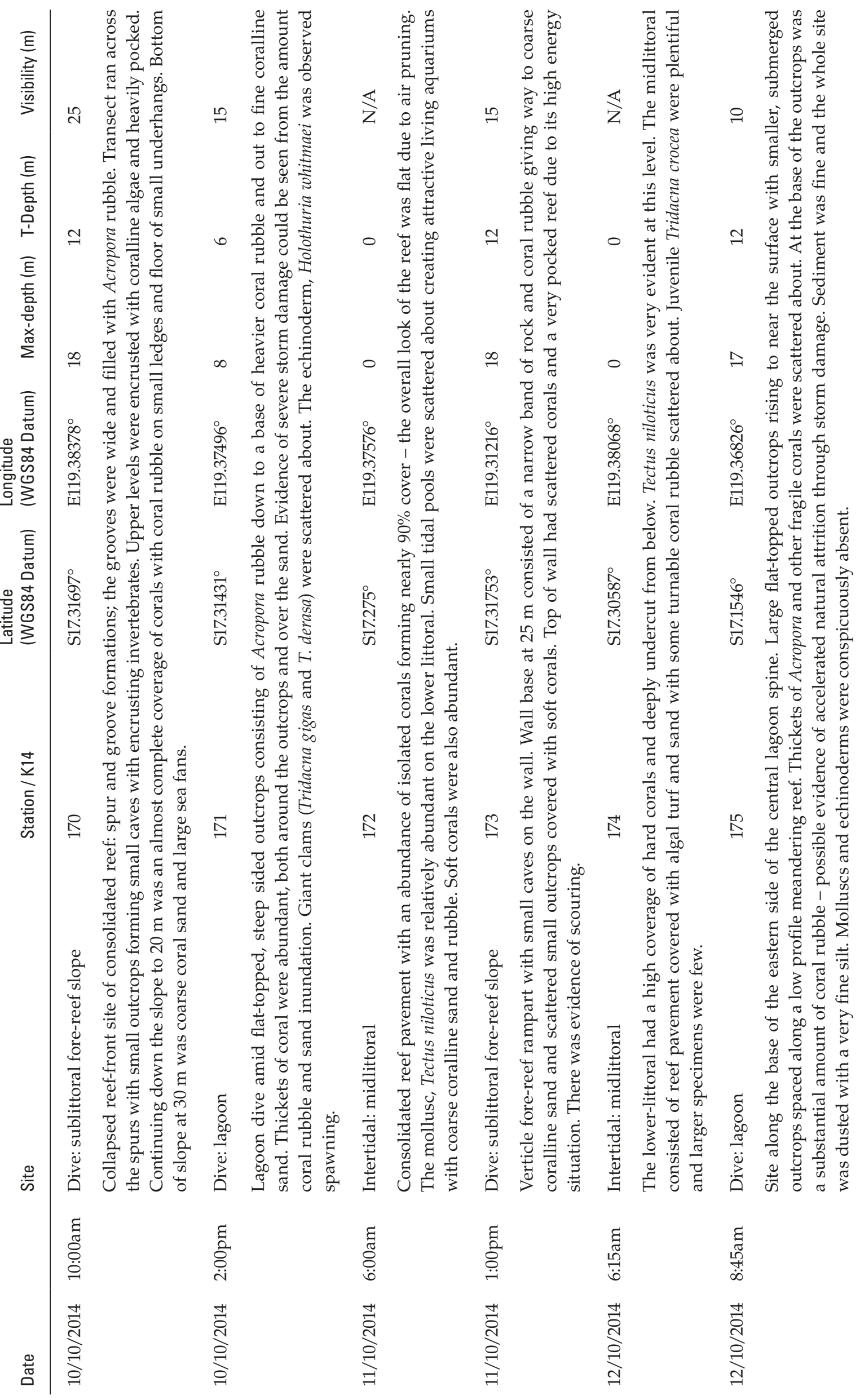




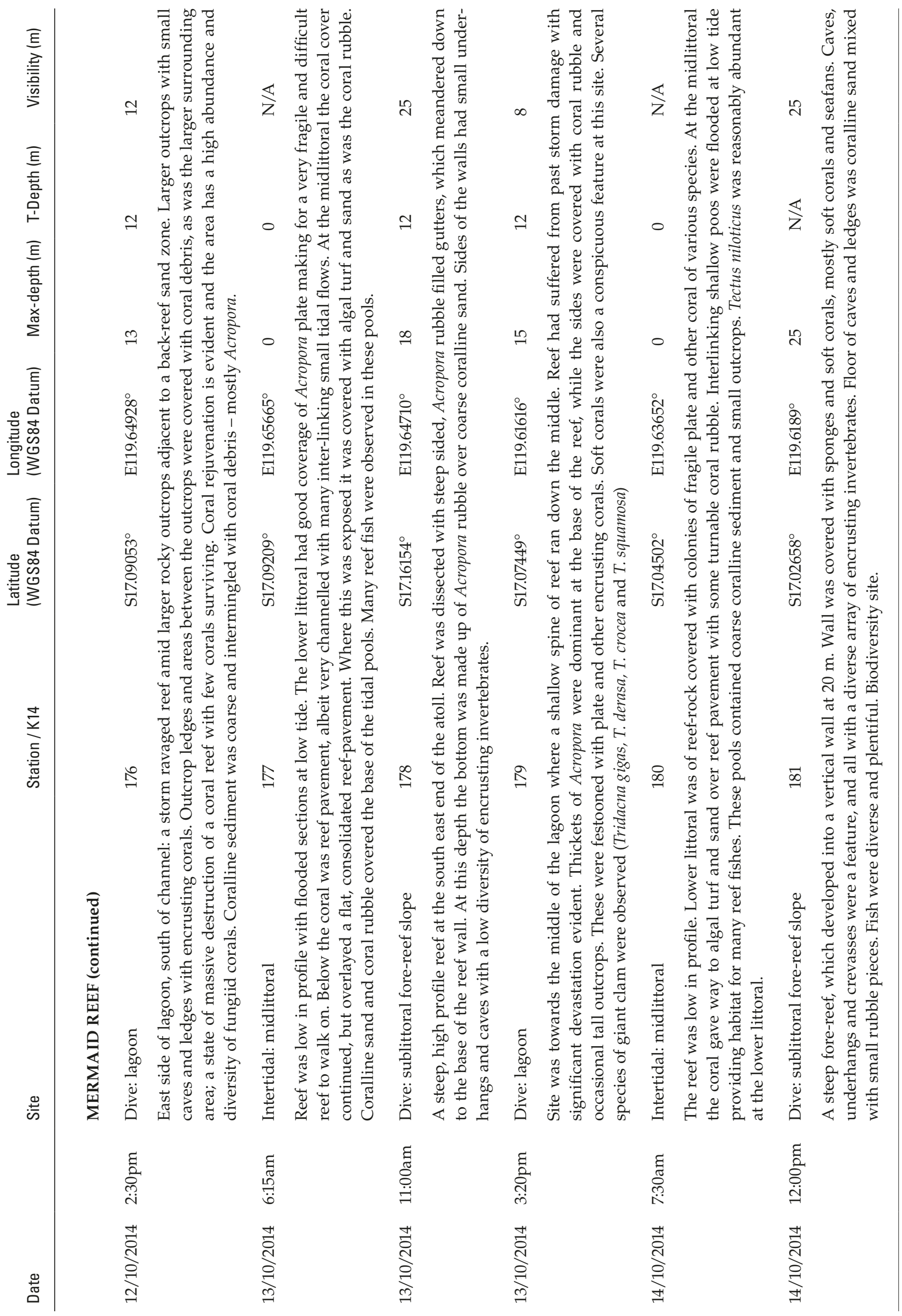


TABLE 2 Surveyed Project locations with year completed. The number of sampling days and stations completed, and an indication of cross-shelf zoning with totals are also annotated. Cross-shelf zoning: $I=$ Inshore; $\mathrm{M}=$ Midshelf; $\mathrm{O}=$ Offshore.

\begin{tabular}{|c|c|c|c|c|c|}
\hline Year & $\begin{array}{l}\text { Sampling } \\
\text { days by year }\end{array}$ & $\begin{array}{l}\text { Sampling locations with replication excluded } \\
\text { (refer to Table } 1 \text { for location details) }\end{array}$ & $\begin{array}{l}\text { Number of } \\
\text { locations } \\
\text { surveyed }\end{array}$ & $\begin{array}{l}\text { Number } \\
\text { of stations } \\
\text { completed }\end{array}$ & $\begin{array}{l}\text { Cross-shelf } \\
\text { zoning }\end{array}$ \\
\hline \multirow[t]{4}{*}{2009} & 12 & Adele Island & & 13 & I \\
\hline & & Montgomery Reef & & 14 & I \\
\hline & & Number stations completed & & 27 & \\
\hline & & Surveyed locations & 2 & 2 & \\
\hline \multirow[t]{4}{*}{2010} & 15 & Cassini Island & & 18 & I \\
\hline & & Long Reef & & 15 & I \\
\hline & & Number stations completed & & 33 & \\
\hline & & Surveyed locations & 2 & & \\
\hline
\end{tabular}

2011

13

Wildcat Reefs

2

Champagney Islands

2

White Island

5

Black Rocks

Un-named outcrop NW Black Rocks

Osborn Reefs

Isolated Reef NW of Wildcat Reefs

Beagle Reef

Mavis Reef

Albert Reef

Brue Reef

Fraser Island

King and Conway Islands

Irvine and Bathurst Islands

Number stations completed

I

5 I

1 I

1

Aborted

Aborted

Surveyed locations

30

Rosella Shoals

De Freycinet Island

Hedley Island

Outcrop North of Colbert Island

Woodward Island

Browse Island

Echuca Shoal

30 


\begin{tabular}{|c|c|c|c|c|c|}
\hline Year & $\begin{array}{l}\text { Sampling } \\
\text { days by year }\end{array}$ & $\begin{array}{l}\text { Sampling locations with replication excluded } \\
\text { (refer to Table } 1 \text { for location details) }\end{array}$ & $\begin{array}{l}\text { Number of } \\
\text { locations } \\
\text { surveyed }\end{array}$ & $\begin{array}{l}\text { Number } \\
\text { of stations } \\
\text { completed }\end{array}$ & $\begin{array}{l}\text { Cross-shelf } \\
\text { zoning }\end{array}$ \\
\hline & & Heywood Shoal & & 2 & M \\
\hline & & Jamieson Reef & & 2 & I \\
\hline & & Condillac Island & & 2 & I \\
\hline & & Patricia Island & & 1 & I \\
\hline & & Heritage Reef & & 1 & I \\
\hline & & West Montalivet Island & & 2 & I \\
\hline & & Robroy Reefs & & 3 & I \\
\hline & & Maret Islands & & 1 & I \\
\hline & & Number stations completed & & 30 & \\
\hline & & Surveyed locations & 15 & & \\
\hline \multirow[t]{6}{*}{2013} & 13 & Ashmore Reef & & 20 & $\mathrm{O}$ \\
\hline & & Hibernia Reef & & 4 & $\mathrm{O}$ \\
\hline & & Vulcan Shoal & & 1 & M \\
\hline & & Eugene Mcdermott Shoal & & 1 & M \\
\hline & & Number stations completed & & 26 & \\
\hline & & Surveyed locations & 4 & & \\
\hline \multirow[t]{7}{*}{2014} & 14 & Mermaid Reef (Rowley Shoals) & & 8 & $\mathrm{O}$ \\
\hline & & Clerke Reef (Rowley Shoals) & & 13 & $\mathrm{O}$ \\
\hline & & Imperieuse Reef (Rowley Shoals) & & 12 & $\mathrm{O}$ \\
\hline & & Number stations completed & & 33 & \\
\hline & & Surveyed locations & 3 & & \\
\hline & & Total stations attempted & & 181 & \\
\hline & & Total stations surveyed & & 179 & \\
\hline Total days & 82 & Total surveyed locations & 38 & & \\
\hline \multirow[t]{6}{*}{2006} & 16 & Mermaid Reef & & 16 & $\mathrm{O}$ \\
\hline & & South Scott Reef & & 14 & $\mathrm{O}$ \\
\hline & & North Scott Reef & & 10 & $\mathrm{O}$ \\
\hline & & Seringapatam Reef & & 5 & $\mathrm{O}$ \\
\hline & & Stations surveyed & & 45 & \\
\hline & & Surveyed locations & 4 & 4 & \\
\hline Totals & 98 & Total surveyed locations & 42 & 224 & \\
\hline
\end{tabular}




\section{STATION AND GEOMORPHIC DATA (THIS PAPER)}

The survey station attributes represent whole of station data and were recorded by the senior author in all cases. They detail survey date, time, location, identifier (station number), station description and coordinates (latitude and longitude), the survey method (dive, snorkel or intertidal walk), maximum station depth, transect depth and horizontal water visibility. The station descriptions contain details such as sediment type, dominant benthic taxa, tide and current information, and other relevant data. 'Maximum station depth' was taken as the deepest depth worked. 'Horizontal water visibility' was used as a proxy to provide an indication of station turbidity and measured at the start of each station as the horizontal distance (in metres) along the transect tape at which discernible shapes could be distinguished. For intertidal stations this measurement was taken as the maximum transect length (100 m).

The 22 geomorphic criteria in Table 3 were assigned to each of the 179 completed stations along with the 45 stations of the 2006 survey (Bryce 2009). These included the three cross-shelf zones (offshore, midshelf and inshore), geomorphic structure (island, reef, shoal or atoll), reefal features (fore-reef, back-reef, lagoon, reef platform) and substratum.

The presence, or absence, of the criterion 'Silt', either as a main substrate or as a dusting over the general topography, was recorded as a proxy for the existence of depositional fine sediments (silt) at each station. Similarly, the presence, or absence, of 'Coralline sands' demonstrated if a station was subject to clear oceanic water, free of any coastal or lagoonal originating sediment. Other criteria, such as 'Sand ripples' provided an indication of strong water flow, and a reef with a 'Vertical or steep dropoff' indicated a high-energy reef-front providing a wave-breaking rampart with high topographic habitat. This is in contrast to the stations with a lower topography ('Flat reef - patch or platform') that would be subject to a different sheering watermovement regime across their surface to that experienced by a vertical wall (Lugo-Fernández et al. 1998; Gourlay 1994).

Patterns of similarity of the sampled stations and those from the 2006 survey (Bryce 2009) were examined using multivariate analyses. This included hierarchical clustering and non-Metric Multidimensional Scaling (nMDS) performed in the software package PRIMER v6 (Clarke and Warwick 2001; Clarke and Gorley 2006). These analyses were based on square-root transformed geomorphic data per station derived from Table 1 and published data from the 2006 survey (Bryce 2009) using a Bray-Curtis dissimilarity coefficient. The patterns were visualised using an nMDS ordination (Figure 2) and a cluster dendrogram, with group-average linkage, to demonstrate the strength of the site relationships (Figure 3). The purpose of this analysis was to examine the similarity of sampled stations in order to complement the analyses undertaken for the targeted taxa data in the following papers of this series.

\section{RESULTS}

\section{GENERAL PROJECT}

Of the 181 survey stations attempted, 179 were completed from 38 locations, with two stations (70 and 71) aborted due to poor water visibility and tidal current (Figure 1 and Table 1). The crossshelf station and location breakdown comprised: 110 inshore stations (28 locations), 12 midshelf (5) and 57 offshore (5). Adding the 45 stations and 4 locations from the 2006 survey (Bryce 2009) increased the offshore representation to 102 stations from 8 locations. In total, 224 stations from 42 locations have been surveyed since 2006 and were included in the analyses of the present paper (Table 2).

Examination of Project locations (Table 2 and Figure 1) at each of the corners of the Project Area demonstrate a greater replication of geomorphic zones (i.e. more stations per location providing finer scale sampling) compared to the surveyed locations between. These corner locations are: offshore northwest at Ashmore and Hibernia Reef (24 stations) and Rowley Shoals in the south-west (33); inshore south-east at Adele Island and Montgomery Reef (27), and Cassini Island and Long Reef (33) in the north-east. These four corners of the Project Area account for 117 stations, while the remaining 34 locations account for the balance of stations (62). The transect habitat coverage implications for this geomorphic zone clustering will be dealt with elsewhere (Richards et al. 2018).

\section{GEOMORPHIC DATA}

Examination of the similarity plot (Figure 2) reveals a three way differentiation of the 224 stations surveyed (2009-2014 and 2006 surveys), which can be identified by cluster (C) numbers. Firstly, by their continental shelf zonation (distance from the coast): inshore clusters (coastal islands and reefs) C3, C5 and C8; midshelf 
TABLE 3 Geomorphic parameters used for Figure 2 and 3 as extracted from Table 1 and Bryce 2009.

\begin{tabular}{|c|c|c|}
\hline Geomorphic criteria & Measurement & Proxy \\
\hline Inshore & coast to $50 \mathrm{~m}$ depth & Distance from coast \\
\hline Midshelf & 51-150 m depth & Distance from coast \\
\hline Offshore & $>150 \mathrm{~m}$ depth & Distance from coast \\
\hline Island & Yes/no & Geomorphic structural influences \\
\hline Reef & Yes/no & Geomorphic structural influences \\
\hline Shoal & Yes/no & Geomorphic structural influences \\
\hline Atoll & Yes/no & Geomorphic structural influences \\
\hline Fore-reef slope & Presence/absence & Water energy + geomorphic structure \\
\hline Back reef/lagoon & Presence/absence & Water energy + geomorphic structure \\
\hline Coralline sands & Presence/absence & Water energy + sediment deposition \\
\hline Dusting of silt & Presence/absence & Water energy + sediment deposition \\
\hline Silt substrate & Presence/absence & Water energy + sediment deposition \\
\hline Sand ripples & Presence/absence & Water energy \\
\hline Slope - sand & Presence/absence & Geomorphic structure + sediment deposition \\
\hline Slope - reef & Presence/absence & Geomorphic structure + water energy \\
\hline Vertical/steep drop-off & Presence/absence & Geomorphic structure + water energy \\
\hline Flat reef - patch or platform & Presence/absence & Geomorphic structure + water energy \\
\hline Rocky/coral outcrops & Presence/absence & Geomorphic structure \\
\hline Maximum station depth & Metres & Subtidal/intertidal influences \\
\hline Horizontal water visibility & Metres of transect & Turbidity \\
\hline Latitude & Decimal degees & Location: north south gradient \\
\hline Longitude & Decimal degees & Location: east west gradient \\
\hline
\end{tabular}

(Browse Island and submerged shoals) C2 and C7; and offshore (continental edge atolls) C1, C4 and C6. Secondly, an intertidal and subtidal distinction can be observed with the intertidal zone represented by $\mathrm{C} 1-5$. This intertidal zone is further divided into walked reef-platform stations (C1-3) and stations SCUBA dived or snorkelled (C4 and $\mathrm{C5}$ ) (indicated by the broken line). Stations in C6-8 were all subtidal and sampled using SCUBA. Other than the intertidal/subtidal distinction, the offshore subtidal stations (C6) can further be defined into quiet lagoonal and high-energy forereef slope sites, thus demonstrating the relative simplicity of the offshore atoll habitats compared to the more complex inshore locations.

Finally, a turbidity gradation can be observed, as indicated by the red arrows within C4-8. The stations within these clusters are arranged from low to high turbidity in line with the direction of the red arrows. The general trend is for increasing turbidity radiating out from the central plot area, represented by the clear water midshelf, and those offshore and inshore stations adjacent to the midshelf. It could be argued that the reverse trend, i.e. one radiating towards the central midshelf from the outer stations of each cluster, would represent increasing energy flow (water movement). This assertion is based on the midshelf stations (C7) and stations close to the midshelf demarcation lines bordering C6 and C8, having coarse coralline sands and fore-reef slopes, i.e. stations at locations sited at the outer demarcation of the inshore, which are also outside any sediment plume and subject to high-energy wave action. In contrast, the outer stations of C6 and C8 had siltier sediments being sited within relatively silty lagoonal/back reef situations or close to 


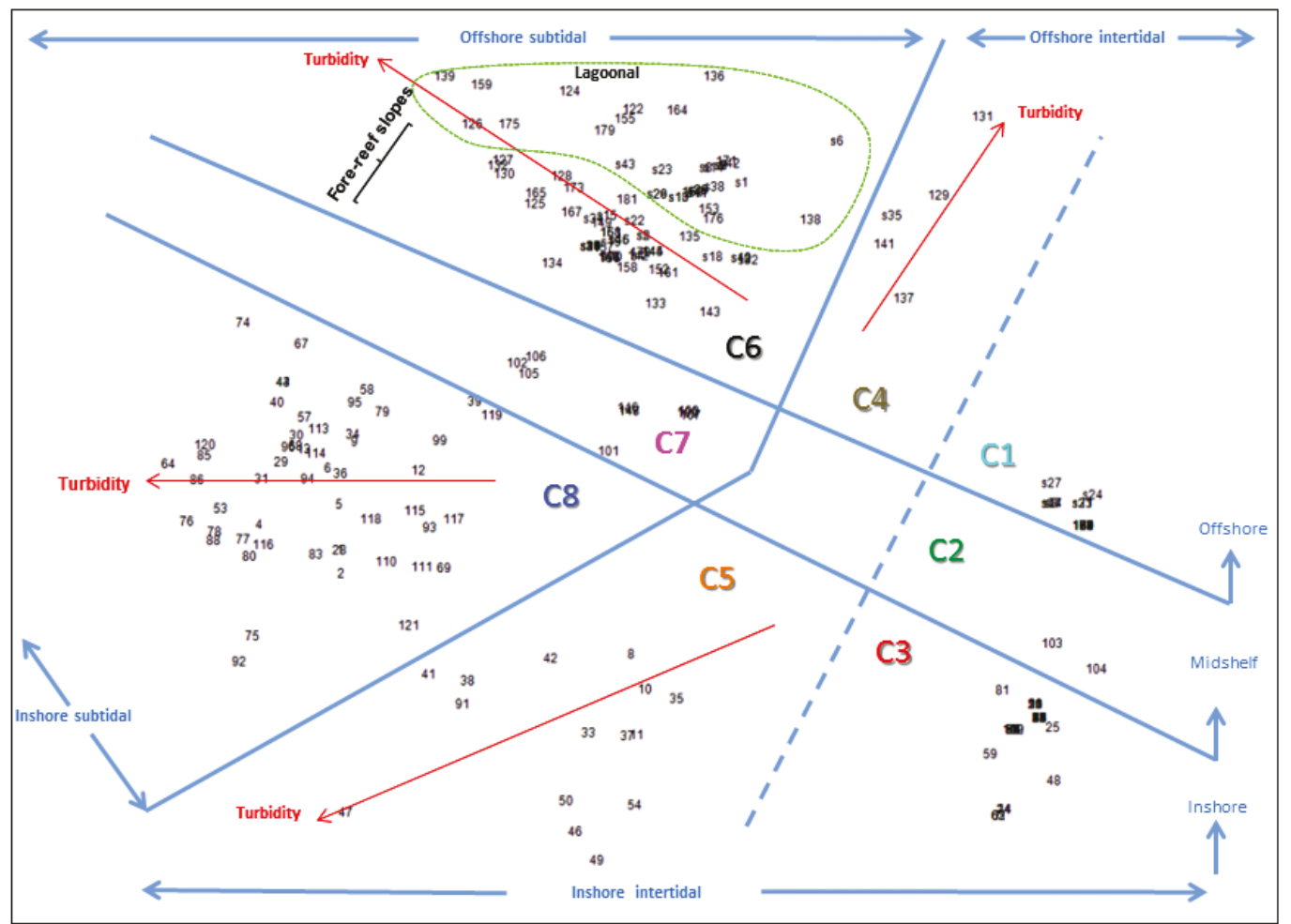

FIGURE 2 MDS ordination of 224 stations surveyed during 2009-2014 (179 stations) and 2006 (45 stations). A three way differentiation of the stations is indicated: intertidal (C1-3 and C4 \& C5) and subtidal (C6-8), inshore to offshore and turbidity. The broken line delineates those intertidal stations walked ( $\mathrm{C} 1-3)$ and those snorkelled or dived (C4 and C5). Colour coded Cluster numbers equate to those used in Figure 3 and Table 4. Final stress in $2 \mathrm{D}=0.14$.

inshore macro-tidal environments. The same is true for $\mathrm{C} 4$ and $\mathrm{C} 5$, but the high to low energy gradient is less pronounced as these stations are intertidal and protected somewhat by their reef ramparts from high-energy wave action. The distance from the midshelf demarcation lines by the closest stations (station 8/K09 in C5 and $137 / \mathrm{K} 13$ in C4) is also indicative. The stations in these two clusters were generally within close proximity to inshore, shallow reefs and islands (C5) or offshore environments with fine sediments (C4).

The hierarchical clustering in the dendrogram (Figure 3) reveals comparable patterns with those seen in the station similarity MDS plot (Figure 2). To provide comparative detail the dendrogram (Figure 3) was maintained as a single figure, with Table 4 supplying the station data/cluster reference and ordered commensurately with that seen in Figure 3. There are two main cluster breaks: intertidal/subtidal (similarity 0.71) and offshore/ inshore (similarity 0.79), with an inter-cluster break for C6 into fore-reef slopes and lagoonal sites (similarity 0.88).

\section{DISCUSSION}

The Project Area is large at approximately $476,000 \mathrm{~km}^{2}$ providing considerable latitudinal and longitudinal gradients, the latter spanning across the shallow water zones $(<30 \mathrm{~m})$ of the wide continental shelf from coast to continental edge. The Kimberley inshore is complex with a high diversity of habitats created by over 2,500 islands and a convoluted ria coastline (Wilson, 2014), which contrasts with the simpler, more well-defined offshore habitats of the deeper reefs, shoals and atolls of the continental slope. The complexity of the inshore is further complicated by the macro-tides and corresponding light-impeding, silt-laden waters. Offshore the environment is oceanic by nature with clear water and greater bathymetric scope and as such, subject to different environmental drivers compared to the inshore. This difference in environmental complexity is demonstrated in Figure 2 with the stations of the offshore subtidal stations (C6), including the subtidal midshelf C7, being closely clustered (greater habitat similarity 


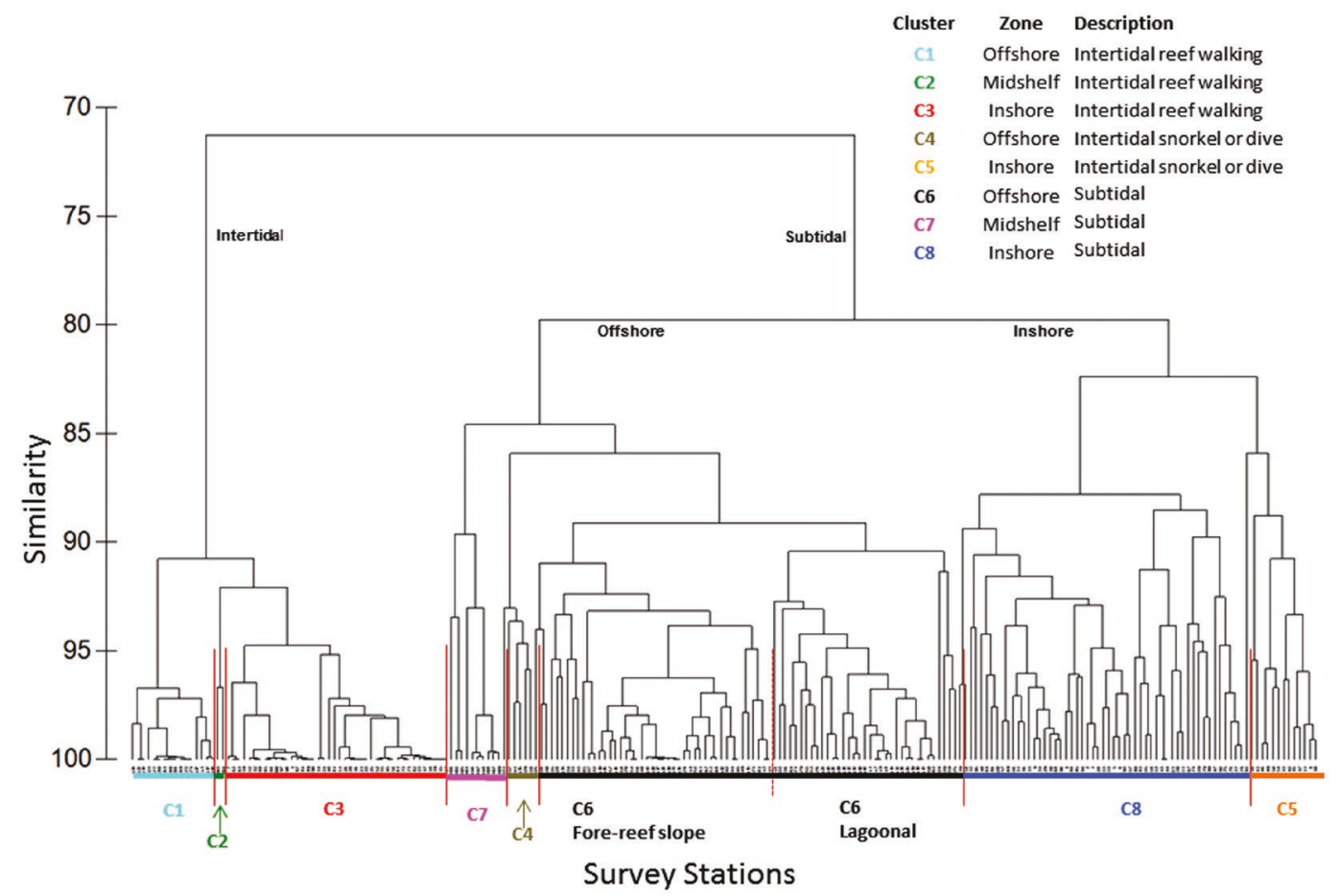

FIGURE 3 Dendrogram for hierarchical clustering of 224 stations (2009-2014 and 2006) throughout the Project Area using group-average linking of the Bray Curtis similarities, calculated on square root transformed habitat data from 20 geomorphic measures (Table 3). Two main cluster breaks are indicated: intertidal (similarity 0.91) and offshore/inshore (similarity 0.85), with a further inter-cluster break for C6 (fore-reef slopes and lagoonal habitats). Colour coded Cluster numbers (C) equate to those used in Figure 2 with full station numbers/cluster in Table 4.

within each cluster), in comparison to the inshore stations (C5 and C8), which have a more loosely clustered aspect (greater habitat diversity). This is also reflected in the intertidal clusters of $\mathrm{C} 1$ and $\mathrm{C} 3$, albeit to a lesser extent.

It is suggested here that the environmental complexity of the subtidal inshore $\mathrm{C} 8$ is further demonstrated in the dendrogram (Figure 3, Table 4). Any attempt to further refine the habitats of this cluster, in a similar fashion as for the offshore subtidal C6 into fore-reef slopes and lagoonal stations, was unresolved and will require further examination and, in all probability, finer metrics than those recorded for this project. The inclusion of biological data (future papers of this project) will undoubtedly help to resolve this issue and enable further analyses.

The distribution of completed survey stations, including those of the 2006 survey, represents a significant contribution to our understanding of the Kimberley marine environments, the habitats, biodiversity and geomorphology. Implementing this project method, with station effort limited to 60 minutes, for sampling a vast area of shallow water environments is easily transferred to other regions and offers adaptability for different situations. The range of targeted marine taxa, with a mix of mobile and sessile phyla, delivers a significant and meaningful assessment of a region's biodiversity, provides insights into the various biogeographic implications of the marine life and places the habitat associations into context. However, the over-riding caveat is that all the recorded data is a snapshot in time and not a comprehensive examination of the changes, seasonal, annual or otherwise, which are so characteristic of this dynamic Kimberley region.

These data provide a foundation to evaluate the region's marine biodiversity and habitats, allowing for informed decision making by government, industry and conservation agencies. These surveys will aid in the determination and management of the region's marine reserve systems, both established and yet to be declared (e.g. Anon 2011, Moore et al. 2016). The outcomes of this project (papers in prep) with the associated data and museum/herbarium research voucher specimens across the nine marine taxa will also provide a foundation for future research as ongoing analyses exposes and identifies knowledge gaps. 
TABLE 4 Survey stations per cluster ordered to match Figure 3 with commensurate location data extracted from Table 1.

\section{Station \# Locations}

\section{C1: Offshore intertidal walking}

s21

\section{C2: Midshelf intertidal walking}

103

Browse Island

104

Browse Island

\section{C3: Inshore intertidal walking}

Adele Island

Champagney Islands

Champagney Islands

Cassini Island

Condillac Island

Cassini Island

Cassini Island

White Island

White Island

Woodward Island

Hedley Island

Hedley Island

Adele Island

Fraser Island

King and Conway Islands

Irvine and Bathurst Islands

\section{Station \# Locations}

Irvine and Bathurst Islands

14

24

Montgomery Reef

Montgomery Reef

48

81

Long Reef

Brue Reef

51

26

\section{C7: Midshelf subtidal}

106

102

105

101
Browse Island

Browse Island

Long Reef

Montgomery Reef

Montgomery Reef

Montgomery Reef

Montgomery Reef

Montgomery Reef

Montgomery Reef

Long Reef

Long Reef

Long Reef

Long Reef

Wildcat Rocks

Beagle Reef

Brue Reef

Montgomery Reef

Montgomery Reef

Montgomery Reef

Montgomery Reef

Montgomery Reef

Montgomery Reef

Browse Island

Browse Island

Vulcan Shoal

Eugene Mcdermott Shoal

Heywood Shoal

Echuca Shoal

Heywood Shoal
Beagle Reef

Echuca Shoal 


\section{Station \# Locations}

\section{C4: Offshore intertidal dive/snorkel}

131

Ashmore Reef

Ashmore Reef

Ashmore Reef

141

s35

129

138

C6: Offshore subtidal fore-reef slopes

125

126
Ashmore Reef

Ashmore Reef

Ashmore Reef

Ashmore Reef

Ashmore Reef

North Scott Reef

Ashmore Reef

Ashmore Reef

Hibernia Reef

Imperieuse Reef (Rowley Shoals)

Ashmore Reef

Ashmore Reef

South Scott Reef

Seringapatam Reef

Imperieuse Reef (Rowley Shoals)

Mermaid Reef (Rowley Shoals)

Imperieuse Reef (Rowley Shoals)

Clerke Reef (Rowley Shoals)

Clerke Reef (Rowley Shoals)

Clerke Reef (Rowley Shoals)

Ashmore Reef

Seringapatam Reef

South Scott Reef

South Scott Reef

South Scott Reef

South Scott Reef

North Scott Reef

North Scott Reef

Mermaid Reef (Rowley Shoals)

Mermaid Reef (Rowley Shoals)

Clerke Reef (Rowley Shoals)

Imperieuse Reef (Rowley Shoals)

\section{Station \# Locations}

167

151

168

s22

142

144

145

149

s15

173

181

s2

s5

\section{C6: Offshore subtidal lagoonal}

s6

122

136

164

171

179

155

153

176

s23

s43

s26

s29

s18

s12

s32

s40

s42

s1

s7

s9

s8

s14

s11

s38

s25
Imperieuse Reef (Rowley Shoals)

Clerke Reef (Rowley Shoals)

Imperieuse Reef (Rowley Shoals)

South Scott Reef

Hibernia Reef

Hibernia Reef

Hibernia Reef

Mermaid Reef (Rowley Shoals)

Mermaid Reef (Rowley Shoals)

Clerke Reef (Rowley Shoals)

Mermaid Reef (Rowley Shoals)

Mermaid Reef (Rowley Shoals)

Mermaid Reef (Rowley Shoals)

Mermaid Reef (Rowley Shoals)

Ashmore Reef

Ashmore Reef

Imperieuse Reef (Rowley Shoals)

Clerke Reef (Rowley Shoals)

Mermaid Reef (Rowley Shoals)

Clerke Reef (Rowley Shoals)

Clerke Reef (Rowley Shoals)

Mermaid Reef (Rowley Shoals)

South Scott Reef

Seringapatam Reef

South Scott Reef

South Scott Reef

South Scott Reef

Mermaid Reef (Rowley Shoals)

North Scott Reef

North Scott Reef

Seringapatam Reef

Mermaid Reef (Rowley Shoals)

Mermaid Reef (Rowley Shoals)

Mermaid Reef (Rowley Shoals)

Mermaid Reef (Rowley Shoals)

Mermaid Reef (Rowley Shoals)

Mermaid Reef (Rowley Shoals)

North Scott Reef

South Scott Reef 


\begin{tabular}{|c|c|c|c|}
\hline Station \# & Locations & Station \# & Locations \\
\hline s39 & North Scott Reef & 5 & Adele Island \\
\hline s10 & Mermaid Reef (Rowley Shoals) & 6 & Adele Island \\
\hline s13 & Mermaid Reef (Rowley Shoals) & 93 & White Island \\
\hline 150 & Mermaid Reef (Rowley Shoals) & 117 & West Montalivet Island \\
\hline 162 & Imperieuse Reef (Rowley Shoals) & 80 & Brue Reef \\
\hline 124 & Ashmore Reef & 83 & Brue Reef \\
\hline 139 & Ashmore Reef & 115 & Heritage Reef \\
\hline 159 & Imperieuse Reef (Rowley Shoals) & 118 & Robroy Reefs \\
\hline 175 & Clerke Reef (Rowley Shoals) & $\begin{array}{l}53 \\
43\end{array}$ & $\begin{array}{l}\text { Long Reef } \\
\text { Long Reef }\end{array}$ \\
\hline C8: Insho & ubtidal & 44 & Long Reef \\
\hline 39 & Cassini Island & 121 & Robroy Reefs \\
\hline 58 & Cassini Island & 110 & Jamieson Reef \\
\hline 12 & Adele Island & 111 & Jamieson Reef \\
\hline 95 & De Freycinet Island & 67 & Black Rocks \\
\hline 40 & Cassini Island & 74 & Beagle Reef \\
\hline 64 & White Island & 119 & Robroy Reefs \\
\hline 86 & King and Conway Islands & 79 & Albert Reef \\
\hline 120 & Maret Islands & 99 & Outcrop North of Colbert Island \\
\hline 57 & Long Reef & 47 & Long Reef \\
\hline 69 & Un-named outcrop NW Black Rocks & 92 & Wildcat Rocks \\
\hline 116 & West Montalivet Island & 75 & Beagle Reef \\
\hline 31 & Cassini Island & 76 & Mavis Reef \\
\hline 36 & Cassini Island & 77 & Mavis Reef \\
\hline 13 & Adele Island & 78 & Mavis Reef \\
\hline 9 & Adele Island & C5: Insho & ntertidal dive/snorkel \\
\hline 34 & Cassini Island & 91 & Rosella Shoals \\
\hline 29 & Cassini Island & 38 & Cassini Island \\
\hline 30 & Cassini Island & 41 & Cassini Island \\
\hline 68 & White Island & 46 & Long Reef \\
\hline 96 & Hedley Island & 49 & Long Reef \\
\hline 4 & Adele Island & 50 & Long Reef \\
\hline 88 & King and Conway Islands & 54 & Long Reef \\
\hline 85 & Fraser Island & 33 & Cassini Island \\
\hline 94 & De Freycinet Island & 42 & Cassini Island \\
\hline 2 & Adele Island & 35 & Cassini Island \\
\hline 1 & Adele Island & 37 & Cassini Island \\
\hline 28 & Cassini Island & 11 & Adele Island \\
\hline 113 & Condillac Island & 8 & Adele Island \\
\hline 114 & Patricia Island & 10 & Adele Island \\
\hline
\end{tabular}




\section{ACKNOWLEDGMENTS}

The Western Australian Museum and its partner agencies respectfully acknowledge the Traditional Custodians of the Kimberley land and sea country, of Elders past and present, and in particular the Dambimangari and Wunambal Gaambera peoples, for collections made on their sea country.

We would like to acknowledge and thank Stacey Osborne, Jenelle Ritchie and Mark Salotti for their tireless technical expertise, Ana Hara for her mapping skills and the accommodating and ever-helpful crews of the Kimberley Quest II. This project was funded by Woodside Energy and the Western Australian Museum and the authors would like to acknowledge their continued support.

\section{REFERENCES}

Anon (2011) Kimberley Science and Conservation Strategy, Department of Environment and Conservation, Perth, Western Australia.

Bryce, C.W. (2009). Station and transect data for Mermaid (Rowley Shoals), Scott and Seringapatam Reefs, Western Australia. Records of the Western Australian Museum Supplement 77: 1-27. doi: 10.18195/issn.0313-122x.77.2009.001-027

Clarke, K.R. and Gorley, R.N. (2006). PRIMER v6 user manual. PRIMER-E, Plymouth.

Clarke, K.R. and Warwick, R.M. (2001). Changes in marine communities: An approach to statistical analysis and interpretations, $2^{\text {nd }}$ edition. PRIMER-E, Plymouth.

Gourlay, M.R. (1994). Wave transformation on a coral reef. Coastal Engineering 23: 17-42. doi:10.1016/03783839(94)90013-2

Halpern, B.S., Walbridge, S., Selkoe, K.A., Kappel, C.V., Micheli, F., D'Agrosa, C., Bruno, J.F., Casey, K.S.,
Ebert, C. and Fox, H.E. (2008). A global map of human impact on marine ecosystems. Science 319: 948.

Jones, D., Bryce, C., Fromont, J., Moore, G. (eds) (2017). Marine biodiversity of the Kimberley 1880s2009. Records of the Western Australian Museum Supplement $\mathbf{8 4}$.

Lugo-Fernández A., Roberts, H.H. and Suhayda, J.N. (1998). Wave transformations across a Caribbean fringing-barrier coral reef. Continental Shelf Research 18:1099-1124. DOI: 10.1016/S0278-4343(97)00020-4

Moore, C.H., Radford, B.T., Possingham, H.P., Heyward, A.J., Stewart, R.R., Watts, M.E., Prescott, J., Newman, S.J., Harvey, E.S., Fisher, R., Bryce, C.W. (2016). Improving spatial prioritisation for remote marine regions: optimising biodiversity conservation and sustainable development trade-offs. Scientific Reports 6: 32029

Richards, Z.T., Bryce, M., Bryce, C. (2018). The composition and structure of shallow benthic reef communities in the Kimberley, NW Australia. Records of the Western Australian Museum Supplement 85: Submitted.

Risk, M. J. (1972). Fish diversity on a coral reef in the Virgin Islands. Atoll Research Bulletin. 193: 1-6. doi: 10.5479/si.00775630.153.1

Sampey, A., Bryce, C., Osborne, S. and Miles, A. (2014). Kimberley marine biota. Historical data: introduction and methods. Records of the Western Australian Museum Supplement 84: 19-43. doi: 10.18195/issn.0313-122x.84.2014.019-043

Wilson, B.R. (2014). Kimberley marine biota: historical and environmental introduction. Records of the Western Australian Museum Supplement 84: 1-18. doi: 10.18195/issn.0313-122x.84.2014.001-018

Wood, M. and Mills, D. (eds) (2008). A turning of the tide: science for decisions in the Kimberley-Browse marine region. Western Australian Marine Science Institute: Perth. Unpublished report. 